\title{
Tax Culture: Perspectives from an African State
}

\section{Raymond A. Atuguba}

Dean and Associate Professor, School of Law, University of Ghana, GHANA

E-mail for correspondence: atugubaatuguba@yahoo.com

\begin{abstract}
Universally, Tax Culture is not a very common topic but it is critical to administrative governance and economic development. This article argues that the Tax Culture of any milieu is an assemblage of various indices and criteria. These include: the history of taxation; tax laws; tax information; tax education; tax revenue mobilisation; tax system transparency; tax delinquency; tax dispute resolution; and taxpayer satisfaction. The article sheds light on these instrumental wheels of the Tax Culture of Ghana by providing the research results of field surveys conducted a decade and a half ago. Though dated, any observer of the Tax Culture of Ghana, and indeed of much of Africa and the Global South, will realise that little has since changed. In some instances, the article provides more up-to-date evidence beyond the 2005 data. The article goes beyond an assessment of the Tax Culture of Ghana and articulates recommendations for improving the same. Additionally, it attempts to interconnect issues of Taxation, Good Governance and Legal Pluralism. Although popular themes in public discourse in Africa today, these concepts are often spoken of in different thematic spheres other than taxation. The article links these themes in practical and concrete ways to taxation, cast in the light of historical institutionalism - an examination of the institutions of taxation, governance and traditional authority as they interacted through time.
\end{abstract}

Keywords: Africa, Ghana, Tax Culture, Good Governance, Legal Pluralism, Traditional Authority, Chieftaincy, Tax History, Tax Laws, Tax Information, Tax Education, Tax Revenue Mobilisation, Tax System Transparency, Tax Delinquency, Tax Dispute Resolution, Taxpayer Satisfaction

\section{INTRODUCTION}

"Question: What do you understand by tax?

Answer: You spend your time working and somebody thinks you do not deserve it and because he has power over you he takes some from it."

"Question: Why would you not want to pay tax?

Answer: I actually feel pains in my body when I pay tax ${ }^{11}$

The research project on Tax Culture, which this article springs from, was initiated in order to solicit from the Ghanaian people their opinions and expectations about the payment of tax in general, with the potential aim of establishing the Tax Culture of Ghanaians. The study also aimed to examine the role of traditional authority and decision makers in encouraging voluntary tax compliance, enhancing tax mobilization and assisting with tax dispute resolution.

First, we conducted research into the historical and cultural context of taxation in Ghana. This was meant to provide a clearer understanding of the context in which modern systems of taxation operate. The overall aim was to bring this learning to bear on efforts at improving good governance in tax administration in Ghana and improving professionalism in Ghanaian tax officials on the one hand and voluntary tax compliance by the populace on the other. Thus, the results of this study could assist in the development of an effective tax collection and tax administration policy for the country.

The underlying assumption of the research project is that we can better appreciate the internal mechanism of a tax system by examining the economic behavior of

${ }^{1}$ These are direct responses from interviewees during field research that was undertaken for the research project (on file with author). 
communities to which the tax system applies. A tax system, which is structured to reflect the history and culture of the community to which it applies, will have a better chance of maximizing efficiency and equity in the processes of raising revenue.

\section{Taxation and National Development}

Taxation is an important public policy tool for raising government revenue. An overarching reason for tax imposition is that the development of a nation depends largely on it, and without adequate revenue development efforts will be hampered. Encapsulated in the phrase "no taxation without representation", issues of taxation have the added potential to shape the political participation of citizens. Parliamentarians, serving as the embodiment of a constituencies and a manifestation of the sovereign will and interests of their constituents, ordinarily engage with the executive branch to discuss, agree on and operationalize rules and systems for the size, scope and mobilization of taxes for financing public institutions and development projects. These discussions necessarily extend to direct community consultations with citizens and other social institutions. It includes deliberations on which development projects should be financed by the taxpayers' money.

Factually, not everybody is comfortable with paying taxes. In Ghana, governments and the people are generally critical and careful about taxation for three historical reasons. First, the payment of taxes has come to be evidence of subordinate status and disempowerment, as victorious states and tribes imposed taxes on the vanquished; secondly, tax issues have historically motivated and encouraged political mobilization and; lastly, a history of overt corruption and opulence by politicians, presumably living off taxpayers' monies, has meant that many question the use to which taxes are put.

Vassal states in pre-colonial Ghana paid taxes to their overlord states which would have previously conquered them ${ }^{2}$; and colonial subjects paid taxes to the colonial government to foot the bill of the colonial enterprise. ${ }^{3}$ Tax

\footnotetext{
${ }^{2}$ Baku, K. (2003) 'Chieftaincy in Africa: Culture, Governance and Development'. Paper presented at the Summary of International Conference Proceedings at the International Conference Centre. Accra Ghana, January 6-10 2003.; Adeyiga G. K. (2013) ‘Baseline Study Of Ghana's Tax System'. Commissioned by Ghana Integrity Initiative (GII) in collaboration with OXFAM America with funding from German International Development (GIZ). September 2013, Accra. DOI: $\quad$ http://maketaxfair.net/assets/Ghana-Baseline-study310713.pdf

${ }^{3}$ Ibid Baku (2003)

${ }^{4}$ Ibid Baku (2003)

${ }^{5}$ Boafo-Arthur, K. (2013) Ghana: One Decade of the Liberal State. Zed Books Ltd., Accra.

${ }^{6}$ Annan, N. (2014) 'Violent Conflicts and Civil Strife in West Africa: Causes, Challenges and Prospects'. Stability: International Journal of Security and Development, 3(1), p. Art. 3. DOI: http://doi.org/10.5334/sta.da
}

issues have also historically provided fodder for political mobilization. A good example is the political mobilization by pro-independence movements that surrounded the imposition of the Poll Tax in the mid-nineteenth century. ${ }^{4}$ Another is the political mobilization by opposition forces around the introduction of Value Added Tax (VAT) in Ghana in $1995 .{ }^{5}$ In both cases, the broader demands for independence and for less onerous living standards (in the case of the 1995 events) were conveyed to the government and the national and international publics through the proxy of an "oppressive" tax regime. Lastly, since independence, corruption has been a key factor of national governance, leading to violent and peaceful overthrows of governments across time. ${ }^{6}$ Electoral victories are now very much dependent on the reality or perception of corruption amongst key members of the government. The favorite accusation that is traded by political parties is that their memberships are feeding fat on tax revenue that is illegitimately acquired. ${ }^{7}$

For all the above reasons, it is critical not to divorce a system of taxation as a technical process from the broader political, economic and social undertones which are the baseline for taxation. We cannot seek to transform our system of taxation to one that is more equitable, better governed, transparent and covers a wider net without considering the "tax culture" of Ghanaians.

\section{Ghana's Recent DeVelopment Trajectory and THE ROLE OF TAXATION}

From the early 1990s, tax reforms have been the fulcrum for broader economic reforms in developing countries. Over this period, a main objective of all governments of Ghana has been to increase public revenues by: enlarging the tax base; improving tax mobilization techniques; introducing consumption-based taxes such as Value Added Tax (VAT); and attempting to elevate the equities of tax administration by improving transparency and reducing corruption and tax evasion. In addition to these, more recent goals include reducing tax exemptions and plugging revenue loopholes and leakages with the hope of improving revenue administration. ${ }^{8}$ While governments

${ }^{7}$ Falguera E., Jones S. \& Ohman M. (eds) (2014) Funding of Political
Parties and Election Campaigns: A Handbook on Political Finance.
International Institute for Democracy and Electoral Assistance,
Sweden.
${ }^{8}$ National Development Planning Commission (NDPC) (2003) Ghana
Poverty Reduction Strategy (GPRS) (2003-2005): An Agenda for Growth
and Prosperity. Accra, Ghana. February 19, 2003. p. 61; National
Development Planning Commission (NDPC) (2005) Growth and
Poverty Reduction Strategy (GPRS II) (2006-2009). Accra, Ghana.
November 2005. p. 66; National Development Planning Commission
(NDPC) (2010) Ghana Shared Growth and Development Agenda (GSGDA)
(2010 - 2013). Accra, Ghana. December 2010. p. 19; National
Development Planning Commission (NDPC), (2014). Ghana Shared
Growth and Development Agenda (GSGDA II) (2014-2017) Vol 1: Policy
Framework. Accra, Ghana. December 2014. p. 32; Ministry of Finance
and Economic Planning (2017) 'The Budget Statement and Economic
Policy of the Government of Ghana for the 2017 Financial Year'. Page 26 American Jaurnal of Trade and Policy • Vol $8 \bullet$ Issue I/2021 
can do little in the short run to change the structural determinants of tax revenue, they can alter other factors that influence tax revenue such as economic policies, the level of corruption and the quality of tax administration. In many developing countries, the wide divergence between the tax actuals ${ }^{9}$ and tax potential ${ }^{10}$ indicates that there is scope for raising tax revenue without increasing tax rates by reinforcing tax and customs administration, encouraging voluntary tax compliance, reducing and eliminating some tax exemptions, and fighting fraud and corruption. ${ }^{11}$

In African countries, experts have warned that tax reform efforts will continue to be modest due to the low levels of development and the heavily agricultural and informal character of their economies. ${ }^{12}$ Again, the costly fight against corruption in the tax collection and administration system needs to be undertaken on several fronts if tax reform efforts are to be successful. Furthermore, tax mobilization and reform can be achieved only when there is strong political will and leadership to adopt the necessary measures.

In the absence of sufficient tax revenues to bankroll development projects, many low-income countries like Ghana rely on external development assistance to support budgetary implementation. Despite some improvements in revenue generation, tax revenue has only been enough to finance between 25 and $35 \%$ of total budgetary expenditures. ${ }^{13}$ The government is well aware of the need to change the aid-dependent nature of the economy, yet admits that there is little that can be done in the short-term to change the situation. Ghana's President mentioned in his first State of the Union Address that, "Today, as a result of policy choices, we find ourselves in a situation where Ghana's total revenue is consumed by three main budgetary lines: wages and salaries, interest payments and amortization, and statutory payments. These three items alone account for 99.6 per cent of

Presented to Parliament on Thursday, 2nd March, 2017 by Ken Ofori-Atta Minister for Finance. pp. 3 and 42; Office of the Presidency (2017) 'The State of The Nation Address by The President of The Republic, Nana Addo Dankwa Akufo-Addo', on The Occasion of The State Opening of Parliament on Tuesday, February 21, 2017. p. 4; Centre for Energy Policy Analysis (2005), 'Multi-Donor Direct Budget Support in Ghana: The Implications for Aid Delivery and Aid Effectiveness'. Ghana Selected Economic Issues (CEPA, 2005) No. 11 at p. 3.

${ }^{9}$ Tax actuals are the tax revenues raised by government's tax collection agencies within a given period.

${ }^{10}$ Tax potential is the quantum of taxes that can be raised within a given period based on the tax rate imposed by the legislature and the taxpayers who ought to pay these taxes.

${ }^{11}$ Levin, J. \& Thisen, J. K. (2003), 'Optimal Commodity Taxation Efficiency and Equity Aspects'. Paper Presented at Ad-Hoc Expert Group Meeting, Economic Commission for Africa, on Fiscal Policy and Growth in Africa themed "Fiscal Federalism, Decentralization, and the Incidents of Taxation", 7-9 October 2003, UNCC, Addis Ababa, p. 2

${ }^{12}$ Mavungu, M. N. and Krsic, N. (2017), 'Assessing the Impact of Tax Administration Reforms in Sub-Saharan Africa', Paper for Munich Personal RePEc Archive, MPRA Paper No. 89275, DOI: https://mpra.ub.uni-muenchen.de/89275/ government revenue. This means that anything else that government has to do outside these lines, will have to be financed by borrowing or aid. The persistent resort to borrowing for any additional expenditures to meet the aspirations of our people is also not sustainable. We cannot continue this way with our public finances." ${ }^{14}$ The President would go on to develop a "Ghana Beyond Aid Policy"15, based in part on improved tax mobilization and anticorruption.

\section{Research Methodology}

There is inherent tension between the state and the citizen when it comes to tax matters. Although it is conceivable that citizens should be ready and willing to pay taxes, which are used for public goods for the benefit of all, they often prefer a free-rider's attitude and avoid taxation as much as possible. Voluntary tax compliance is therefore an issue. Flowing from the above, an inclusive state must ensure that tax collection is based on transparent and contestable rules that are implemented in a fair manner to encourage voluntary tax compliance. Transparency and accountability in the tax system are all the more crucial as the tax administration deals with money, with the attendant issues of unofficial payments and corruption.

A well-functioning tax system can be a valuable instrument for fostering growth and development. The cultural approach to taxation seeks to rationalize the efficiency of a tax system by examining the past and present economic behavior of societies to which the system applies. Notwithstanding an objective analysis based on economic data, the subjective effects of societal conditioning will impinge on the efficiency of any tax system and alter the outcomes, whether positively or negatively. A tax system which is fashioned with an understanding of the cultural values of the society in which it is to apply has a better chance of maximizing tax revenue

${ }^{13}$ According to The Budget Statement and Economic Policy of the Government of Ghana for the 2010 Financial Year Presented to Parliament on Wednesday, 18th November, 2009 by Dr. Kwabena Duffuor, Minister of Finance and Economic Planning, the total tax revenue for the year 2009 was GHC 3,249 million against a total expenditure of GHC 10,618.9 million. This means tax revenue contributed to only $31.4 \%$ of the total expenditure. A decade later, The Budget Statement and Economic Policy of the Government of Ghana for the 2020 Financial Year Presented to Parliament on Wednesday, 13th November, 2019 by Ken Ofori-Atta, Minister for Finance showed that total tax revenue in 2019 was GHC 26.6 billion whereas the total expenditure was GHC 84.5 billion. Thus the tax revenue was barely $30.5 \%$.

${ }^{14}$ Office of the Presidency (2017) 'The State of The Nation Address by The President of The Republic, Nana Addo Dankwa Akufo-Addo', on The Occasion of The State Opening of Parliament on Tuesday, February 21, 2017. p. 4

${ }^{15}$ Office of the Presidency (2018) President Akufo-Addo Outlines Policies For 'Ghana Beyond Aid, The Presidency, Republic of Ghana, $7^{\text {th }}$ March 2018. Available at http://presidency.gov.gh/index.php/briefingroom/news-style-2/569-president-akufo-addo-outlines-policies-forghana-beyond-aid. [Accessed on $10^{\text {th }}$ December 2020.] 
yields. Even the way in which revenue is collected by the state mirrors its respect for the citizen's rights; hence the importance of this research topic on tax culture.

Until now, no comprehensive study has been conducted into the historical and cultural context of taxation within Ghana. It is generally assumed that the majority of Ghanaians are tax averse. Yet, this is precisely an assumption. Our research project sought to fill this void by conducting the first tax culture study for Ghana, establishing a definition of tax culture for Ghana, providing a measurement of Ghana's tax culture, conveying a number of findings on the elements that constitute Ghana's tax culture and making a number of recommendations for improving Ghana's tax culture.

The research project started with brainstorming on the appropriate project design and then the subsequent development of a program document. This was followed by preliminary research on a number of issues that have a bearing on the tax culture of Ghana. The purpose of the preliminary research was to refine the project document and assess the information and knowledge that was necessary for designing field research instruments. In all, six preliminary research reports were prepared on the following subject areas: the historical and cultural context of taxation and systems of governance; the chieftaincy system and its role in resource mobilization; the system of local governance and resource mobilization; the economic behavior of Ghanaian residents as it relates to taxation; taxation and legal pluralism in Ghana; and traditional methods and forms of taxation and how they may be incorporated into a modern tax system.

The preliminary reports were then used to design a semistructured questionnaire for interviews with chiefs, a structured questionnaire for interviews with individual taxpayers and to finalize the project document and map out a research strategy. Once the questionnaires were designed, they were piloted in Accra, reviewed and then finalized. During the review of the questionnaires and the pre-departure orientation that was held for field research staff, the translation and rendition of key words in the questionnaires into the key local languages of the research regions was completed.

Part of the research strategy involved testing the assumptions about Ghana's tax culture by talking to chiefs and the Ghanaian public; women and men from the formal and informal sector. In all, 29 chiefs (including 3 Queen mothers and 7 Registrars of Houses of Chiefs ${ }^{16}$ ) and 1,002

\footnotetext{
${ }^{16}$ The Registrars of the various Houses of Chiefs in Ghana and Officials at the National Chieftaincy Secretariat are very well versed in matters of tradition because of their long or concentrated interactions with the custodians of Ghanaian tradition - chiefs and queen mothers.

${ }^{17} 934$ respondents said they were Ghanaian. 68 respondents refused to answer to their nationality. Due to some historical reprisals against non-Ghanaians in Ghana, they were unwilling to openly admit that they are non-Ghanaians.
}

individual Ghanaian ${ }^{17}$ resident taxpayers were interviewed. There were 7 Paramount Chiefs, 6 Divisional Chiefs, 3 Chiefs, 3 Headmen, 3 Queen mothers and 7 Registrars from five regions ${ }^{18}$ in Ghana in the research sample.

The interviews with the chiefs were done with a qualitative semi-structured interview instrument. Chiefs have historically had a revenue mobilization mandate in Ghana. They also play a critical role in national development issues and taxation is a national development issue. It was expected that the chiefs would have very insightful views on the tax culture of Ghanaians; we were not disappointed.

About half of the number of chiefs interviewed had been chiefs for over 10 years. They were all aged between 40 and 100 years. The mean age group was $40-60$ years. Almost all of the chiefs had had some formal education; more than half at the secondary and tertiary levels. All but one belonged to recognized trades and professions; a third of the number belonging to the formal sector. They also belonged to diverse ethnic groups: Ga, Ashanti, Ewe, Fante, Gonja, Sefwi, Nzema, Sisala, Dagomba, and Mamprusi. The chiefs ruled over subjects ranging in number from a thousand to over a million.

As mentioned earlier, we also conducted interviews with 1,002 Ghanaian residents using a structured questionnaire. For the individual taxpayers, 205 women, 795 men and 2 persons who did not indicate their gender, from all walks of life, were interviewed. ${ }^{19}$ Respondents included teachers, lawyers, bankers, nurses, accountants, policemen, development workers, herbalists, traders, hairdressers, sales managers, administrators, mechanics, artisans, businessmen and women, spare parts dealers, farmers and tailors. We administered twice as many questionnaires in the Greater-Accra and Ashanti Regions as in the Western, Volta and Northern Regions. This is because the populations of the two regions are the highest in the country. Respondents were aged between 15 and 65 and their levels of education ranged from basic education to tertiary education. Of the total number of individual taxpayer respondents, 589 were from the formal sector and 217 were from the informal sector. A good number of respondents, 196, could not identify which sector they belonged to, or declined to answer the question. Over $70 \%$ of respondents were employed by others and only $10 \%$ were self-employed.

The field research lasted one month. During the piloting of the questionnaires, we encountered a number of

\footnotetext{
${ }^{18}$ The Regions from which the Registrars were interviewed are Greater Accra Region, Western Region, Ashanti Region, Volta Region and Northern Region.
}

${ }^{19}$ Many potential female interviewees declined to be interviewed. Where they were with their husbands, they referred the research assistants to their husbands. 
difficulties with respondents, relating mainly to their unwillingness to answer questions bordering on taxation, and sometimes mistaking the field researchers for tax officials. These difficulties escalated during the administration of the finalized questionnaires. In the case of the chiefs, we had beforehand written to the five registrars of the Houses of Chiefs in the five research regions. This greatly facilitated the process of getting access to the chiefs and having House of Chiefs staff accompany us to the various residences of the chiefs we interviewed. In July 2005, a presentation of the preliminary findings of the research project was made to the National House of Chiefs in Kumasi. The House of Chiefs made very useful comments and suggestions after the presentation.

The interviews and interactions with individual taxpayers were more challenging. The challenges encountered during the piloting of the questionnaires were a good forewarning, even if a foreboding one. For quite interesting reasons, most people were very reluctant to grant the interviews; excuses were many and varied, ranging from being too busy, to an inability to talk due to an aching wisdom tooth, even though this latter excuse was given by a person who was actively engaged in a conversation with a colleague before the field research assistant made her request. One woman who was reading newspapers in her office said she was too busy to talk and actually asked the research assistant to leave. Some of our field research staff had to buy items from the shops of respondents in the informal sector in order to motivate them to fill out the questionnaire.

People were generally nice until they found out the subject for discussion: tax. They became suspicious and apprehensive as soon as they heard the word "tax" and, understandably so, refused to speak. One respondent kept asking one of our staff if she had a tape recorder in her bag. There was open hostility from some people who assumed our field staff were from the Internal Revenue Service (IRS) ${ }^{20}$. Some of our staff got scolded several times. One respondent in the Northern Region explained her fear and reluctance. Two years earlier, a gentleman walked into her shop and bought some items. He demanded a receipt, which she gave to him. She was arrested later because she did not issue a VAT receipt. Apparently, the gentleman was from the Criminal Investigations Department (CID) of the Ghana Police Service.

Regional and District managers of companies with their headquarters in Accra were very reluctant to answer simple questions relating to how long they had been doing business in the region and the number of employees in the company until they received the requisite permission from their head offices in Accra.

${ }^{20}$ In 2009, as part of the revenue reforms in Ghana, the Internal Revenue Service (IRS) was merged with the Customs Excise and Preventive Service (CEPS) and the Value Added Tax Service (VATS) to form the Ghana Revenue Authority.

${ }^{21}$ Nerré, B. (2001) 'The Concept of Tax Culture', Paper prepared for the Annual Meeting of the National Tax Association, November 8-10, 2001.
Some respondents complained that they had been through many such exercises in the past with no practical results; they were therefore reluctant to fill the questionnaires or respond to questions posed by the field staff. Others complained that previous researchers had made promises to them (like promising to send them a copy of the report), which were never followed through. There was a general feeling on the part of individual taxpayers of being used and abandoned by researchers. It is not surprising, therefore, that some of the respondents wanted to be paid for answering the questions. Some police officers interviewed very openly asked for tips.

The process was generally successful, revealing and interesting, making up for the usual hitches. And even the hitches provided some quaint comic relief to field research staff walking and working in the scorching sun and hunting down reluctant taxpayer respondents. A German Field research staff noted the following in the daily journals that they kept: "Two of the interviewees stopped the interview at the point at which they had to express their own opinion and I was not able to motivate them to continue it. Sometimes it was a bit difficult to handle the situation; one person asked me to pay him for doing the interview and some wanted to be taken abroad. When I explained that the questionnaire would give them an opportunity to voice their opinions, they started and finished without complaining".

\section{Tax Culture}

Someone once remarked at the Annual Meeting of the German Association for the History of Economics in Hamburg that tax culture is a very interesting and important topic but nobody writes about it! ${ }^{21}$ This is very true. This research report is one of the first on tax culture in any country in the world, and definitely for Ghana. In many other countries, practically nothing has been written on the subject.

It is important to fully understand the concept of tax culture before attempting to assess Ghana's tax culture. As hammered on, within the Ghanaian context, no studies have been conducted into the historical and cultural context of taxation. Yet, the administration of a municipal system of taxation will be difficult in the absence of such culturally specific studies. The general assumption that the majority of Ghanaians are tax averse is what is often used as the main proxy for measuring the country's tax culture. Our research has revealed that the use of that proxy may be fundamentally flawed. In the words of one chief we interviewed, "It is only an insane person who will not pay tax".

Baltimore, MD, USA, p.2 DOI: http://www/worldbank.org/publicsector/tax/norms/pdf 
It is well known that the administration of any system of taxation is influenced by a broad range of geographical, political, economic, social and psychological factors - both historical and current. The importance of research into the tax culture of a society lies in the fact that a tax system, which is fashioned with an understanding of the cultural workings of the society in which it is to apply, has a better chance of ease and efficiency of administration. "Tax culture matters! There is no such thing as a 'free bunch' of tax reform measures that can be applied universally." 22 What then is tax culture?

Tax Culture is a term that is easy to define but difficult to appreciate. This is because a major component of the definition of tax culture is "culture", and culture is anything but easy to appreciate. It is the entirety of the mores, way of life, norms, customs, conventions, traditions, ideas, values, beliefs, behavioral strategies, perceptual models, organizational structures, tools, techniques, works of art, rituals, symbols, civilization - so to speak - of a community, nation or region. "A countryspecific tax culture is the entirety of all relevant formal and informal institutions connected with the national tax system and its practical execution, which are historically embedded within the country's culture, including the dependencies and ties caused by their ongoing interaction" ${ }^{23}$ It is not only the tax system and the actual tax practice that form part of a country's "tax culture"; the relationship between the tax authorities and the taxpayers also accounts for the unique "tax culture" of a country. The concept of tax culture is broader than the concepts of "culture of taxation" and "tax paying culture". ${ }^{24}$

Tax culture encompasses not just the science of taxation taxation as crafted by politicians and tax experts and economists, and as administered by tax men - but also the art of taxation, that is the common understanding and experience of taxation by the taxpayer. In the best-case scenario, this latter matter will involve the eradication of tax illiteracy, leading to a tax consciousness that generates voluntary tax compliance within a framework of transparent tax laws that are applied humanely and consistently. This clearly shows that tax culture goes

\footnotetext{
${ }^{22}$ Nerré, B. (2002) 'Croatian Tax Culture: Asset or Constraint in the Transformation Process?'. Paper presented at the International Conference on Unofficial Activities in Transition Countries: Ten Years' Experience. Institute of Public Finance, Zagreb, Croatia. 18 th $^{\text {th }} 19^{\text {th }}$ October 2002. Sponsored by the Friedrich Ebert Foundation and Institut Za Javne Financije. p. 11; Livingston, Michael. (2006), “From Milan to Mumbai, Changing in Tel Aviv: Reflections on Progressive Taxation and 'Progressive' Politics in a Globalized but Still Local World", 54 Tax Law: International $\mathcal{E}$ Comparative Tax eJournal DO 10.2139/ssrn.893263; Avi-Yonah, Reuven et al, Global Perspectives on Income Taxation Law, Oxford University Press; Marian, Omri (2009), "The Discursive Failure in Comparative Tax Law", 58 American Journal of Comparative Law, DO - 10.5131/ajcl.2009.0014
}

${ }^{23}$ Supra 21.p. 2 beyond tax system design, tax legislation and tax administration. Related issues are tax revenue distribution between local and central bodies, how explicit and precise the tax laws are, how violations are sanctioned, which rival interest groups exist in terms of national resource mobilization, what the actual tax mobilization strategies and techniques are and what relationship exists between the tax authorities and the taxpayers.

In sum, the factors that determine a country's tax culture will include amount and mechanisms of revenue mobilization; the degree of voluntary tax compliance; taxpayers' views on the equity of the tax systems; views on whether there are returns on tax payments in terms of social amenities and other public goods; cultural values like "honesty", "justice", and "sense of duty"; the organizational culture of tax (wo)men; tax discipline ${ }^{25}$; tax mentality; tax behavior; tax morality; ${ }^{26}$ tax codes; tax authorities; tax experts' taxpayers; tax communication; tax collection processes; tax compliance; tax carrots and sticks; tax resistance; tax negotiability, deferment and double taxation; tax dispute resolution mechanisms; the use of tax proceeds; accountability for use of tax proceeds; tax documentation (record keeping and access to records); and forms of taxation.

The term tax culture is inclusive of a number of other more specific elements: the understanding of why one has to pay taxes; the citizen's understanding and appreciation of taxes; factors that influence tax compliance such as the fear of sanction; the organizational culture of the tax and revenue services; the relationship between tax officials and taxpayers and the resulting behavioral patterns; tax authorities and the individual taxpayer's competencies; how explicit and precise the tax laws are; how violations are sanctioned; the history of taxation and tax institutions of the society in question; the corruption or perceived corruption either on the part of the tax officials or on the part of the taxpayers; and attitudes towards cheating on taxation. Tax culture, therefore, includes all attitudes and also all patterns of behavior which the tax-paying citizens hold about taxation and the state.

${ }^{24}$ Nerré, B. and Blumenthal, K. (2003) 'Tax Culture and Austrian Economics: A Case Study of the Big 1896 Tax Reform'. Paper No. 68 presented at the National Tax Association's 96th Annual Conference on Taxation. Chicago, USA, November 2003. DOI: https:// docplayer.org/8240844-Tax-culture-and-austrian-

economics.html p. 5: "The latter [tax paying culture] resembles the by definition taken more narrowly - tax mentality that consists of the two components of tax morale and tax discipline and solely aims at the relationship of the taxpayer to the tax state".

${ }^{25}$ Tax discipline reflects the attitudes of the taxpayer in meeting his or her tax obligations.

${ }^{26}$ Tax moral is used to describe willingness to pay taxes, borne out of a feeling of obligation to the state because one obtains some benefits from the State, the general public or the community or because one is able to pay taxes. 
From the elements of tax culture listed above, it becomes evident that understanding a specific country's tax culture requires a lot of research effort. This is because many actors, institutions, procedures and processes and their interactions have to be studied to determine the tax culture of a country; the more reason why good policy advice should not disregard the national tax-cultural constraints. This way, the prevention of tax culture shocks and the reduction of tax culture lags should become easier to achieve. ${ }^{27}$

Tax Culture, like all social institutions, evolves: it is not static. This is because culture is consistently undergoing modification processes stimulated by external and internal factors. This is understandable since culture is a dynamic phenomenon of interaction and not a fixed set of processes for actors. This also means that the evolution of tax culture is closely tied to the systems and persons that determine this evolution. Thus, politicians, tax policy makers and tax administrators must strive to bring the tax administration of their countries up to speed with the changing times and trends. This is especially so for tax administrators and collectors since they are at the frontline (serving as the interface between politicians and policymakers on the one hand and the taxpayers on the other) and have a unique capacity to determine the tax culture of the country.

Tax culture is part of national culture or the culture of a society. We can therefore have tax culture shocks. Shocks in the field of tax culture can emerge during an encounter with an unknown or foreign tax culture. The Poll Tax Ordinance that was introduced in Ghana in $1852^{28}$ was a tax culture shock. A tax culture shock occurs when there is an attempt to transfer a particular tax system into a different "tax culture" following a "big-bang" approach. In such cases, "tax culture shocks" are unavoidable. With smoother "gradualist approaches", serious shocks might be avoided. Shocks may be experienced at the individual or micro level, or at the collective or macro level. ${ }^{29}$ The successful demonstrations in Ghana in $1995^{30}$ against the introduction of VAT were mainly because the political opposition were able to mobilize a broad range of people

${ }^{27}$ Supra 21 p. 20.

${ }^{28}$ Metcalfe, G. (1955) 'AFTER MACLEAN: Some Aspects of British Gold Coast Policy in the Mid-nineteenth Century'. Transactions of the Gold Coast \& Togoland Historical Society, 1(5), 178-192. DOI: http://www.jstor.org/stable/41406591 p.187

${ }^{29}$ Supra 21 p.14.

${ }^{30}$ Osei, P. (2000) 'Political Liberalisation and the Implementation of Value Added Tax in Ghana.' The Journal of Modern African Studies, 38(2), 255-278. DOI: http://www.jstor.org/stable/161651 p. 255

${ }^{31}$ Supra 21 p.18.

${ }^{32}$ Adeyiga G. K. (2013) 'Tax Reform Study In Ghana's Tax System'. Make Tax Fair [Online]. Outcome of the Baseline Study on the Tax System which was commissioned by the Ghana Integrity Initiative (GII) partnering Oxfam Novib in Ghana. DOI: https://maketaxfair.net/assets/ActionResearch-Ghana.pdf p. 29

${ }_{33}$ Ablordeppey, S. D. (2016) Fund Managers Rubbish 1\%. Graphic Online, 4 January 2016. Available at https://www.graphic.com.gh/business/business-news/fund- who experienced tax culture shocks at the individual level, and then sensitized them into thinking of the shocks in broader, more systemic and macro terms. This way, the micro tax culture shocks were transposed to a macro tax culture shock, leading to the demonstrations and the eventual withdrawal of the VAT by the government.

There may also be tax culture lags. This occurs when the different elements of a nation's tax culture develop at different speeds so that the relationship between some parts is no longer in cultural and evolutionary equilibrium. This might be due, for example, to a new democratic dispensation which automatically leads to some tax reforms or the introduction of a new tax code. First, tax authorities will have to cope with the new laws and guidelines. Then taxpayers will have to adjust their behavior to the latest changes in the tax laws. During this period of multi-level adjustments, tax-cultural distortions are inevitable. ${ }^{31}$ It is possible that there was a tax culture lag in Ghana following the introduction of the Tax Code titled "Internal Revenue Act" in 2000 and the many tax reforms in the few years after that. ${ }^{32}$ This was also the case with the introduction of another Tax Code, the Income Tax Act, in $2015^{33}$ and again with the abolishing of some nuisance taxes and the changes in the VAT rates for categories of businesses when a new Government took over in Ghana in January 2017. ${ }^{34}$ It is important to note that tax culture lags can hardly be avoided, even if a gradualist approach has been chosen as a method of reform. ${ }^{35}$

In sum, tax culture is the way of life of a people as it pertains to tax. This should encompass everything of any conceivable relevance and sometimes even what seems to be irrelevant. The tax culture of a country is unique only to that country. We should include in the definition of Ghana's tax culture, historical considerations including the tax issues during colonialism, cultural considerations in the ordinary sense of the word, and current considerations including a sense of national frustration with many aspects of governance ${ }^{36}$, national indiscipline on many fronts ${ }^{37}$ and donor dependency. ${ }^{38}$

managers-rubbish-1-tax-fund-managers-rubbish-1-tax.html [Accessed on 13th December 2020]; Boateng, C. (2018) Maintenance Expense Limits - Things Need to Change. SCG Chartered Accountants, 14 September 2018. Available at https://www.scg.com.gh/2018/09/14/maintenance-expense-limitsthings-need-to-change/ [Accessed on $13^{\text {th }}$ December 2020]

${ }^{34}$ Katako G. (2018) The Effects of the Proposed Changes in VAT in Ghana. SCG Chartered Accountants, 23 July 2018. Available at https://www.scg.com.gh/2018/07/23/effects-proposed-changesvat-ghana/ [Accessed on $14^{\text {th }}$ December 2020]

${ }^{35}$ Supra 21 p.19-20.

36 Zainulabideen, F., \& Iqbal, Z. (2009), 'Taxation and Good Governance and the Influence of Non-Tax Revenues on a Polity: The Pakistani Experience'. Policy Perspectives, 6(2), 73-98. DOI: http://www.jstor.org/stable/42909238

${ }^{37} \mathrm{Ibid}$

${ }^{38}$ Mbatia C. N. (2017), 'Effect of Foreign Aid Dependency on Taxation Revenue in Sub-Saharan Africa'. A minor dissertation submitted in partial fulfilment of the requirements for the award of the degree of Master of 
It is obvious from the detailed explanation of the concept that tax culture is very difficult to measure. ${ }^{39}$ This is because it includes many and varied attributes; historical, cultural, social, economic, political, psychological, geographical. For the purposes of this article, I will examine the following elements of the tax culture of Ghana:

1. Tax and Resource Mobilization History of Ghana

2. Tax Laws

3. Tax Information

4. Tax Education

5. Tax Mobilisation

6. Tax Transparency

7. Tax Delinquency

8. Tax Dispute Resolution

9. Taxpayer Satisfaction

10. Tax and Traditional Authorities.

A discussion and synthesis of all of these elements of the tax culture of Ghanaians should provide an accurate assessment of Ghana's tax culture.

\section{ARE GHANAIANS TAX AVERSE?}

"Nobody likes paying taxes", said the Revenue Authorities Governing Board / GTZ Press Release of Wednesday October $6^{\text {th }}, 2005$. We started our research project and also designed our questionnaires with this assumption. We were wrong.

This came out very clearly in a portion of the Field Research Report by one of the field research assistants in this study. After she had administered over 150 questionnaires to respondents in the Greater Accra Region, she noted: "Some questions were based on the assumption that the respondents would not want to pay taxes" ${ }^{40}$ The following quotation from another of our field researchers is also very instructive: "The notion that Ghanaians are tax averse is not a truism to a large extent. The problem, I realized emanated from the tax system and the attitude of officials from the collection agencies. This was evidenced by the reactions of respondents, especially when it came to the question, 'Why would you not want to pay tax?' Most respondents literally got angry with me for asking that question. To them, they pay taxes and would always fulfil their tax obligations and thus the question seemed either

Commerce specializing in Economics. Faculty of Commerce, University of Cape Town 2017.

${ }^{39}$ Hyun J. K. (2005) 'Tax Compliances in Korea and Japan: Why are they different?' Draft Paper for discussion at the seminar held by the Policy Research Institute, Ministry of Finance, Japan. February, 2005. p. 11. See also, Likhovski, Assaf (2007), '"Training in Citizenship': Tax Compliance and Modernity," Law and Social Inquiry 32, 665.700. accusing or insulting. Upon further explanation however, these respondents calmed down and responded appropriately. It is the tax system and the officials thereof that would make them not want to pay taxes. From their side, as long as they remained in employment they would always pay taxes." ${ }^{\prime 11}$ A last comment from one of our field researchers in the Ashanti Region sums it all up: "My personal impression after this first day is that almost all the interviewees are strongly willing to pay taxes, even without legal obligation. Some of the interviewees said that they do not know much about the tax system and they do not even care, but as taxes are used to develop their country they are willing to pay them. From my point of view, they are extremely honest and trust the system blindly." ${ }^{\prime 2}$

Research appears to prove that Ghanaians are not tax averse - pure and simple. If that is the case, why are we generating less revenue than we could possibly generate from taxation? The 2018 Budget Statement for Ghana, for example, reveals that out of about 6 million taxable Ghanaians, only 1.2 million (a quarter) constitute the tax paying population. Out of this population, 1 million are from the formal sector and only 200,000 are from the informal sector. This leaves about 4.8 million people who are not registered with the tax authorities. ${ }^{43}$ The reasons are not farfetched. The majority of respondents thought that their tax burden was too high. Most respondents lamented the fact that their shops and work places were barricaded by taxmen when they defaulted in their tax obligations, making it impossible for them to fulfil their obligations by working to raise the funds for the purpose. ${ }^{44}$

Respondents had other reasons why they would not pay taxes. They complained that there were not enough tax breaks at the beginning of an enterprise. This means that a lot of money that could be spent to consolidate businesses is used to pay taxes, leading to poor performance and sometimes the collapse of the enterprises. "It is painful that in Ghana one would toil and struggle, raise his own capital, establish his business and just when things start picking up, someone comes to collect taxes from me." ${ }^{45}$ If we add to this the problems associated with raising capital to start a business, the inability of government to provide ready avenues for adequate capital, and the high interest rates on loans, the result is that Ghanaians become unwilling to pay taxes. ${ }^{46}$

${ }^{41}$ Tax Culture Field Research Report, 2005 (on file with author).

${ }^{42}$ Tax Culture Field Research Report, 2005 (on file with author).

${ }^{43}$ Ministry of Finance and Economic Planning (2017) 'The Budget Statement and Economic Policy of the Government of Ghana for the 2018 Financial Year'. Presented to Parliament on Wednesday $15^{\text {th }}$ November, 2017 by Ken Ofori-Atta Minister for Finance.

${ }^{44}$ Atuguba R. (2006) 'The Tax Culture of Ghana.' A Research Report Prepared for The Revenue Mobilisation Support (RMS), Accra February 2006. p. 27

${ }^{45}$ Ibid p. 27

${ }^{46}$ Amadu U. S. (2016) Ghana's workers protest price rises: Thousands demand action following tax rises ahead of election, Anadolu Agency, $21^{\text {st }}$ January 2016. Available 
Tax compliance levels show the need for tax education and tax transparency. It was obvious that more Ghanaians will pay their taxes more willingly if they are aware of why they are paying and if they can see the benefits of what they pay. This is buttressed by some studies done by the Organization of Economic Cooperation and Development (OECD) which reveal that there is a link between tax morale and quality public services. ${ }^{47}$ Lack of services will weaken tax morale, thereby leading to unwillingness to pay taxes on the part of citizens. The result will be low revenue mobilization, making Ghanaians "look" tax averse, when in fact they are not.

\section{Assessing Ghana's Tax Culture}

As far back as 1965, one intelligent observer had this to say: "There can be few countries in the world which impose a wider range of taxes than Ghana. In addition to basic sources of revenue such as income tax, customs duties and excise duties, there are many other taxes (occasionally of a more exotic variety), including the following: stamp duty, entertainments duty, property tax, hotel consumer's tax, excess profits tax, purchase tax, sales tax, foreign travel tax, betting tax, capital gains tax, and estate duty." ${ }^{\prime 48}$ As at 2005, a Press Release issued jointly by the Revenue Agencies Governing Board and GTZ still listed the taxes relevant to the Large Taxpayers Unit ${ }^{49}$ as "VAT, Corporate Income Tax, Pay As You Earn (PAYE), and Excise Duties as well as other Miscellaneous Taxes ${ }^{\prime \prime}{ }^{50}$ In 2017, we can count more than ten different domestic tax types and levies that the Ghana Revenue Authority monitors: Corporate Tax, Personal Income Tax, Vehicle Income Tax (VIT), Tax Stamp for businesses in the informal sector, Stamp Duty, Gift Tax, Capital Gains Tax, Rent Income Tax, Communications Service Tax (CST), Excise Duty, National Fiscal Stabilisation Levy, VAT, the National Health Insurance Levy (NHIL) and the Ghana Education Trust Fund Levy. ${ }^{51}$

Ghanaians are therefore used to heavy taxation. Of the 1002 taxpayers interviewed, 758 regularly pay taxes. This is buttressed by the survey carried out by the Large Taxpayers

https://www.aa.com.tr/en/world/ghanas-workers-protest-pricerises $/ 508155 \#$ [Accessed $10^{\text {th }}$ December 2020.]

${ }_{47} \mathrm{OECD} / \mathrm{The}$ International and Ibero-American Foundation for Administration and Public Policies (FIIAPP) (2015) Building Tax Culture, Compliance and Citizenship: A Global Source Book on Taxpayer Education. OECD Publishing, Paris. DOI: http://dx.doi.org/10.1787/9789264205154-en

${ }^{48}$ Park A. E. W. (1965) 'The Estate Duty Act 1965', Journal of African Law 9(3) pp. 162-165. at p. 162.

${ }^{49}$ Large Taxpayers Unit (LTU) of the Revenue Agency Governing Board (RAGB) was set up in April 2005. The establishment of the LTU as a new one-stop agency was aimed at improving the performance of Ghana's tax administration. LTU is responsible for the administration of all tax liabilities of the 360 large taxpayers (i.e. VAT, Corporate Income Tax, PAYE and Excise Duties as well as other Miscellaneous Taxes).

50 RAGB/GTZ (2005) One-stop Tax Agency enhances customer satisfaction: Evaluation of a customer baseline survey on the Large Taxpayers
Unit. ${ }^{52}$ In this survey, respondents gave high priority to tax compliance; $76 \%$ of respondents see tax evasion as a crime, even though $75 \%$ of them think that the tax burden is too high. Those who show a relatively high resistance to meeting their tax obligations articulate a higher than average willingness of moving towards compliance if there are improved services from tax authorities.

The evidence is that Ghanaians have, in the course of history, voluntarily paid taxes for purposes that are clearly for the common good and for worthy causes. An account of this chapter in Ghana's history is documented by Allot, an anthropologist, who remarks, "In response to an appeal from the new Governor, Winniett - who explained that because of shortage of funds no Judicial Assessors could be stationed in the towns of the principal chiefs - a meeting of chiefs at Cape Coast constituted itself a Legislative Assembly and voted a Poll-Tax of $1 /$ - a head, to be used, inter alia, for 'the general improvement and extension of the judicial system in the interior'. This law - though constitutionally invalid - was accepted and ratified by the government, and adopted (under the title "Poll Tax Ordinance") as the first Ordinance of the Colony."

Ghanaians have traditionally regarded the payment of taxes and the protection and social provisioning of the State as a quid pro quo. By 1874, the only major source of revenue left for Northern Ghana consisted of caravan tolls on cattle and kola nuts passing through. However, these tolls were deliberately abolished by the British Administration in 1908 with the object of inducing the cattle traders of Upper Volta to bring down more of the livestock to Ashanti where the Public Health Department had launched a massive eat-more-meat campaign. The removal of the caravan tolls did not result in an increase in the supply of livestock in Ashanti; on the contrary, it reduced the supply for the cattle traders regarded the payment of the tax as entitling them to government protection, and were thus not certain of safety of life and

Unit, RAGB/GTZ Press Release, Monday, March $21^{\text {st }} 2005$ (On file with author).

${ }^{51}$ Sections 1(1), 2, and 5 of the Value Added Tax Act, 2013 (Act 870); Section 1 of the Income Tax Act, 2015 (Act 896); Section 86 of the National Health Insurance Act, 2003 (Act 650); Section 3 of the Ghana Education Trust Fund Act, 2000 (Act 581); See also: http://www.gra.gov.gh/index.php/tax-information/income-tax

[Accessed 10th December 2020]. In 2015, Ghana passed a new income tax law which treats "Gift Tax" and "Capital Gains Tax" as ordinary income taxes.

${ }^{52}$ German Technical Cooperation (2004) Large Taxpayers Unit Survey. German Technical Cooperation (GTZ), April 2004.

${ }^{53}$ Allott, A. N. (1957) 'Native Tribunals in the Gold Coast 1844-1927. Prolegomena to a Study of Native Courts in Ghana' Journal of African Law 1(3), pp 163-171 at p.166. 
property on the highway to Ashanti since "protection money" was no longer demanded from them. ${ }^{54}$

In the light of the above discussion, it is difficult to understand the various mass anti-tax demonstrations that we have experienced in Ghana. When this was brought to the attention of the chiefs we interviewed, they restated the proposition that Ghanaians are not tax averse and added that the social movement activities that surrounded the introduction of the Poll Tax in 1852 and the introduction of VAT in 1995 were immediate causes of more systemic dissatisfactions with the systems of governance in the country. The Poll Tax demonstrations were a proxy for the broader campaign against taxation without representation (and the use of tax revenues to finance foreign colonial enterprises) and the VAT demonstrations were a proxy for a broader campaign against harsh economic conditions.

Similarly, in January 2016, the government implemented new tax handless which saw some areas previously exempted from taxes being taxed; taxes on individual interest earnings, value added taxes on financial services and taxes in the agriculture sector. ${ }^{55}$ About three weeks after government started implementing some of these tax handles, many Ghanaian workers across the country took to the streets in protest against increases in utility tariffs and prices of petroleum products; protests which left many workplaces empty including schools, markets and courts. ${ }^{56}$ The demonstrations were not primarily against increases in taxes but a general sense of economic hardship and increasing perceptions of corruption. ${ }^{57}$

Our respondent Chiefs added that the ways in which tax administrators executed their mandate could also discourage Ghanaians from meeting their tax obligations. In their experience from mobilizing revenue from stool subjects, most of their subjects are very willing to pay taxes and seek out those who collect taxes in order to meet their tax obligations. A majority of respondents said they would pay taxes even if it were voluntary and not compulsory, and this is the case even though the majority of individual respondents think their tax burden is too high or high. Respondents did not also know what percentage of the taxes generated from the district assemblies and from national tax authorities go to their direct benefit and that of their communities.

\footnotetext{
${ }^{54}$ Dickson, K. B. (1968) 'Background to the Problem of Economic Development in Northern Ghana.' Annals of the Association of American Geographers 58(4), pp 689-696, at p. 689.

${ }^{55}$ CitiFm Online (2016) The Income Tax (Amendment) Act, 2016, (Act 907) replaced the Internal Revenue Act, 2000 (Act 592). CitiFm Online Available at http://citifmonline.com/2016/01/04/178811/ [Accessed on $13^{\text {th }}$ July 2017]

${ }^{56}$ Akwa N. S. (2016). Workers hit streets across Ghana to protest high cost of water, electricity. JoyNews Online.
} http://www.myjoyonline.com/news/2016/January-20th/workershit-streets-across-ghana-to-protest-high-cost-of-water-electricity.php Accessed 13th July 2017
Others think that there is too much official opulence and vulgar extravagance and that the tax authorities are not honest in the light of persistent rumors that they help people underpay. The majority of respondents thought that the tax system was not transparent and that in the event that the tax authorities improved their services, it would be easier for them to fulfil their tax responsibilities and furthermore add to their willingness to pay taxes. Again, in respect of the following matters, a majority of individual taxpayer respondents were dissatisfied with the tax authorities: convenience, competence, fairness, readiness to cooperate, providing support, clarity and comprehensibility of decisions, and information about legal tax obligations. It is not surprising that only 219 respondents out of the 1002 individual taxpayer respondents were satisfied with the tax system generally.

Respondents also doubted the real benefits of paying taxes. "I do not see the benefit of paying tax" was a common refrain. One chief in the Greater Accra Region lamented that after several years of paying taxes there is no potable drinking water in his community and no good roads. To him, Ghanaians are too poor and there are too many taxes: "One puts up a small kiosk with one bottle of beer to sell and this attracts a levy from the Assembly." He, however, believes that Ghanaians as a whole could benefit from taxes and so "it is only an insane person who would not pay tax". It is therefore possible that the increases in VATlike levies in the years 2000 and 2004 have been accepted because the increases have been targeted at specific projects: the Ghana Educational Trust Fund (GETFund) and the National Health Insurance Scheme (NHIS).

The willingness of Ghanaians to pay taxes and the fact that Ghanaians are not tax averse is summed up in one of the recommendations in a recent report on the funding of governance institutions as follows: "given the willingness of Ghanaians to pay more taxes to strengthen the solvency of governance institutions, this specific study could explore how additional revenues could be raised through taxation." 58

Taxation in Ghana has historically had a strong governance flavor. Tax protests in Ghana have been linked to representative government (Poll Tax Ordinance of 1852) and poor economic governance (VAT demonstrations of 1995). The corollary of the use of a poor system of taxation

\footnotetext{
${ }^{57}$ Supra 46. "'We are already burdened so why would the government put us through more pain?' protestor Julius Mensah told Anadolu Agency. 'They have increased water, electricity, petrol and now they want us to pay more tax.'".

${ }^{58}$ National Governance Programme (Ghana) \& Ghana Center for Democratic Development (2004) 'The Funding of Key Governance Institutions in Ghana: Report of a Diagnostic Study'. $6^{\text {th }}$ National Governance Workshop 2003, Accra, National Governance Programme (NGP). DOI: http://books.google.com/books?id=FxG0AAAAIAAI pp. 9 and 139.
} 
as a fulcrum for mass mobilization against poor systems of governance is that a good system of taxation can be used for mass mobilization of revenues for development purposes. In the words of Mick Moore, "The more government income is 'earned', the more likely are statesociety relations to be characterized by accountability, responsiveness and democracy". ${ }^{59}$

Ghana's tax culture is best captured in this contradictory quote from one of our field reports: "As a general observation for the whole week, I would say that almost all of the interviewees were strongly convinced that their tax burden was too high, but as I asked how much they pay, they couldn't answer. A lot of the respondents expressed also quite strongly their willingness to pay taxes, but finally they didn't. Such contradictions often came up. ${ }^{160}$ It is clear that Ghanaians are not tax averse. Yet they do not fully meet their tax obligations. They would, if they saw more benefit from paying taxes; if the system of taxation were more humane, transparent and better administered and if corruption by public officials was minimized. The following data from the individual taxpayers' survey is instructive indeed.

Results from the research pointed clearly in one direction. Ghanaians would love to pay taxes but only if certain conditions are met; if there is an ease of paying taxes, if taxes payable are negotiable and not fixed no matter the circumstances, and if the taxes are used for verifiably good causes. In the absence of these preceding conditions, Ghanaians will hate paying taxes and will not pay taxes. This was the general train of thought in the various field reports - written and oral - from the field research assistants. Only $15 \%$ of respondents found the system of filing taxes convenient - and the majority of these may be public sector respondents whose taxes are deducted from source, making the payment of taxes very easy for them.

During our interviews, there was a sense of mounting frustration at the multiplicity of "taxes". This should hardly come as a surprise as sometimes tax laws are created and changed overnight leaving the Ghanaian taxpayer, who was just beginning to understand the new law, in confusion and having to switch immediately to understand its replacement. For instance, under the immediate past administration, the government passed

\footnotetext{
${ }^{59}$ Wilson Prichard (2009), 'The Politics of Taxation and Implications for Accountability in Ghana 1981-2008'. IDS Working Paper 330, July 2009.

${ }^{60}$ Supra 44.p. 30

${ }^{61}$ Government of Ghana (2016) Ghana Hosts International Seminar On Tax Policy And Administration. All Africa, 29 June 2016. Available at https://allafrica.com/stories/201606301155.html [Accessed on 10th July 2017]

${ }^{62}$ Acquah N. (2016) Terkper justifies tax on pensions and allowances. CitiFm Online, 31 May 2016. Available at http://citifmonline.com/2016/05/31/terkper-justifies-tax-onpensions-and-allowances / [Accesed on 10 ${ }^{\text {th }}$ July 2017]

${ }^{63}$ New Patriotic Party (NPP) (2016) Change: An Agenda for Jobs -
} Manifesto for Election, New Patriotic Party, Accra, Ghana. four new laws as part of tax administration reforms: Value Added Tax Act, 2013 (Act 870), Excise Duty Act, 2014 (Act 878), Customs Act, 2015 (Act 891) and the Income Tax Act, 2015 (Act 896). ${ }^{61}$ The then Minister of Finance faced a lot of protests from the Ghanaian people who expressed their shock and resentment at some new taxes which they found almost "unreasonable" such as taxes on pensions and allowances, even though the government tried to explain that these changes emerged in a search for equity in tax mobilization and to prevent tax evasion. ${ }^{62}$

At the time, the opposition party agreed with Ghanaians on the inconvenience of these taxes, and in their political campaigns promised to address the problem and to shift the focus of Ghanaian economic policy from taxation to production by reducing and abolishing some "nuisance" taxes. They argued that taxes did not have to be increased to earn more tax revenue. ${ }^{63}$ When the opposition won the elections, the new government proposed to abolish taxes for some select sectors as well as reduce levies of social amenities. ${ }^{64}$ This led to the passage of new laws and the institution of a new tax regime. ${ }^{65}$ These are just a few examples of how tax laws and systems change often and can be very confusing to the average taxpayer.

Another challenge that was noticed during field research was that respondents could not distinguish between taxes, fees, tolls and other payments. A regular complaint was that "there are too many people taking monies from us market tolls, parking tolls, sanitation tolls, local government levies, IRS taxes". This complaint was often immediately followed by assertions of corruption in government and statements to the effect that Ghanaians do not trust that the monies they pay will be used judiciously and for the right purposes.

In June 2017, when the government announced an impending implementation of a mandatory "tow levy", the suggestion was met with outrage from citizens and vehicle users in the country. The relevant law was passed in 2012, with a 5-year moratorium. ${ }^{66}$ However, when the Ministry of Transport announced the implementation of the law two weeks before the set date, it faced general public disapproval and criticism. There was a lot of uncertainty as to how the levy was to be utilized and monitored. Given the huge public outcry, the levy was suspended. ${ }^{67}$

\footnotetext{
${ }^{64}$ Ministry of Finance and Economic Planning (2017) 'The Budget Statement and Economic Policy of the Government of Ghana for the 2017 Financial Year'. Presented to Parliament on Thursday, 2nd March, 2017 by Ken Ofori-Atta Minister for Finance.

${ }^{65}$ See Income Tax (Amendment) Act, 2016 (Act 907) and 2019 (Act 1007); Special Petroleum Tax (Amendment) Act, 2017 (Act 942) and 2018 (Act 965); Special Import Levy (Amendment) Act, 2017 (Act 944) and 2019 (1004); and Customs and Excise (Petroleum Taxes and the Petroleum Related Levies) (Repeal) Act, 2017 (Act 943).

${ }^{66}$ Road Traffic Regulations 2012, Regulation 102(3).

${ }^{67}$ Mordy, J. T. \& Ibrahim, A. (2017) Controversial mandatory towing levy suspended. JoyNews. 19 June 2017. Available at http://www.myjoyonline.com/news/2017//une-
} 
Individuals and owners of broken-down vehicles now pay a service fee for the cost of mandatory towing services after the services have been delivered ${ }^{68}$ The truth is, ten years after our research, Ghanaians still cannot differentiate between taxes, levies, fees, and other payments required of them. This proves the need for a lot of tax education.

There are three other factors that we must note in order to get a full sense of Ghana's tax culture. Our interviews have revealed that in Ghana, the general perception of corruption on the part of public officials who are paid with taxpayers' money is a huge component of Ghana's tax culture. Given that the issue of corruption has in the last two decades seriously engaged the attention of Ghanaians, we interrogated the responses further. From our interviews, it is not so much the affluence of public officials and those close to them that matters, it is the arrogance with which they carry themselves around, the blatancy with which they deny corruption, or the sense of impunity with which they gladly concede corruption. ${ }^{69}$ That is the worry of the Ghanaian; and all these in the face of mounting cost of living and increasing real poverty levels. $^{70}$

Secondly, a great percentage of Ghana's Christian population (which approaches $70 \%$ of the population) pay tithes and other contributions to their churches, graduated according to income levels; usually $10 \%$ of all earnings, official and unofficial. ${ }^{71}$ And they do this conscientiously and gladly - at least most of the time. This is the type of consciousness we need to build in the case of taxation. It is important to note that for most of the Christian population, their church is their first point of call for loans and when illness or other misfortunes strike. If we relate this scenario to the responses we get from the majority of the taxpayers we interviewed (to the effect that they do not pay tax because they are unable to identify the benefits that derive from paying tax), we will be drawing very interesting parallels and points for learning.

Lastly, it is important to note that there are slight regional variations in the tax culture of Ghana. Take the Northern Region for example: many more people in the informal sector in this region (relative to the other regions) do not pay income taxes or are not up to date with their tax

19th/controversial-mandatory-towing-levy-suspended.php

[Accessed 31st July 2017]

${ }^{68}$ Supra 66

${ }^{69}$ Supra 44.p. 35

${ }^{70}$ Supra 46 and 57

${ }^{71}$ Lidzén, L. (2008). 'A Comparative Study of the Social Welfare Provided by Three Christian Churches in Accra, Ghana'. Dissertation Presented to Department of Humanities and Social Sciences, University of Gävle. DOI: http:// urn.kb.se/resolve?urn=urn:nbn:se:hig:diva-466

${ }^{72}$ Supra 44. p. 36

${ }^{73}$ Supra 44.p. 36

${ }^{74}$ Supra 44. p. 36

${ }^{75}$ Introductory part of this section is mostly taken from: Baku, $\mathrm{K}$. (2003) 'Chieftaincy in Africa: Culture, Governance and Development'. obligations. ${ }^{72}$ They explain that the tax authorities are not in touch with them for the purpose of collecting the taxes due. It appears that the Northern Region is assuming the character of a "tax haven". One smart respondent explained that he relocated his business from the Ashanti Region to the Northern Region in order to get away from the watchful eye of the tax authorities in the former region. The field research assistant for the Northern Region noted as follows: "In conclusion it could be seen generally that people of Tamale do not pay taxes, that is, even if they are aware of their obligations to pay tax." ${ }^{73}$

In the Ashanti Region, the picture is a little different. Respondents were generally very interested in the exercise and both formal and informal sector operatives expressed their willingness to pay taxes. It was clear from the interviews that respondents had had consistent contact with tax authorities and were generally meeting their tax obligations. There was, however, evidence that taxpayers knew very little about taxation and the tax system, even if they regularly paid taxes. ${ }^{74}$ To the various elements of the tax culture of Ghana, it is now necessary to turn.

\section{TAX AND RESOURCE MOBILISATION HISTORY OF GHANA $^{75}$}

The history of resource mobilization of a country partially determines her tax culture. What a country is used to is not easily changed and it is easy to build on what is familiar, acceptable and doable.

Historically, and before colonial rule, the chieftaincy institution was the pivot of the whole society; more or less the government of the day. The chief had different departments made up of the Native Court, the Native Police and the Native Treasury. Under the Native Treasury, the chiefs had the power to tax the natives. This tax could be in cash or kind. The taxing system varied from one community to the other. The various sources of revenue included the following: property levies, community welfare levies, land rent, special development contributions, tolls, royalties from traditional councils paid to paramountcies, fundraising during festivals and other festive occasions, levies on game, timber and mineral products, funeral contributions, burial fees and other special levies. ${ }^{76}$ Historically, therefore, Ghanaians have

Paper presented at the Summary of International Conference Proceedings at the International Conference Centre. Accra Ghana, January 6-10 2003.; Adeyiga G. K. (2013) 'Baseline Study Of Ghana's Tax System'. Commissioned by Ghana Integrity Initiative (GII) in collaboration with OXFAM America with funding from German International Development (GIZ). September 2013, Accra. DOI: http://maketaxfair.net/assets/Ghana-Baseline-study-310713.pdf

${ }^{76}$ Owusu Ansah K., Adams A., Ayinsakeya P. A., \& Mohammed Adams (2013) 'The Challenges And Prospects Of Vehicle Incomes Tax Administration In Ghana. A Case Study Of Ghana Revenue Authority, Asokwa'. A Dissertation presented to Kwame Nkrumah University of Science and Technology School of Business, Kumasi in partial fulfilment of the requirements for the degree of BSc. Business Administration. Knust School Of Business, Kumasi, May, 2013. p. 1: 
experienced a variety of tax regimes. These were mainly seasonal (for example during harvest) and event-based (for example during festivals), based on the profession or occupation of a person (for example market women and fisher folks) or based on a person's origin (stranger) or status (stool subject or vassal state).

Information about taxes and the purpose of the tax was often communicated to everyone. This could be done by the town crier or gong-gong beater or at a durbar organized for the purpose. All persons above the age of 21 years had a tax quota, sometimes discriminating on the basis of gender in terms of the amount payable. Those in industry had a special tax quota, and persons who were not permanent residents had a different tax quota. In some places, professionals and identifiable trades such as market women and fisher folk also paid special levies, mostly in kind, for the sustenance of the chief's palace and for ongoing community projects. Special levies were also collected from the lease of land. ${ }^{77}$

The chiefs and elders decided on when to impose taxes and how much tax to impose. These payments were usually made annually. The annual taxes were obligatory for everybody of a certain age and above, from the least citizen to the most important. The tax did not always have to be money; it could be farm produce or fishery resources. There were many mechanisms for collecting these taxes; fundraising could be done on the spot during festivals or fundraising durbars, taxes could be collected by family heads and transferred to the chief's treasury, and house-tohouse collection by the officials of the Native Treasury. Communal labor was also considered a form of resource mobilization. $^{78}$

The amount of tax imposed was often negotiable, depending on a person's circumstances. Disputes that emanated from the collection of levies were referred to the head of the extended family for settlement. It is when such first steps failed that the chief would sit with his Council to decide on the case. This could be an open or closed hearing. Many penalties, including being ostracized, could be imposed on tax defaulters. Other penalties were special fines (foodstuffs, farm animals, drinks or cash), preventing the burial of the dead from a defaulting household, preventing defaulters from farming on community land, assault by the youth for disobeying the Chief's order, physical labor and banishment. ${ }^{79}$

"Before the introduction of tax system in Ghana, the chiefs of the then Gold Coast had their own system of taxing the people to raise funds for their developmental projects. The Fantes call it _'eto' whiles the Ashantes _'asaaseto'"'

${ }^{77}$ Zackaria, A. I. (2013) 'Evolution of Land Rental Arrangements in Rural Ghana: Evidence from Farming Communities in Wa East and Gomoa East Districts of Ghana'. Ghana Journal of Geography, 5(1), pp. 121-141. p. 122-123

${ }^{78}$ Asamoah S. (2018) 'Historical Overview of the Development of Communal Labor from Pre-colonial to Post Independent Ghana'. International Journal of Scientific and Research Publications, 8(4), pp. 10-
The administration of this system of taxation was not cumbersome and was easy to execute because of the allegiance subjects had to their chiefs and the reverence everyone had for chiefs. On the other hand, there were mostly no written records of taxes collected and this made transparency and tax dispute resolution difficult.

With the advent of colonialism, the system of governance which existed before was severely mutilated. All the three departments of the pre-colonial chieftaincy system (Native Court, Native Police and Native Treasury) were abolished. ${ }^{80}$ The chiefs lost most of their power including the power to tax their subjects. However, the colonial administration exploited the old system by using the chiefs to collect taxes for them. The new system of taxation would eventually be regulated by the Native Treasury Ordinance of 1939 which mandated the chiefs to collect taxes in a prescribed form. It is worthy of note here that chiefs were well remunerated for this service. ${ }^{81}$

By the second half of the nineteenth century, British administration had taken a firm root, at least, on the Ghanaian coast. In 1843, two enactments, namely the British Settlement Act and the Foreign Jurisdiction Act, were passed extending British rule to the Gold Coast. Before 1852, tax related issues only took the form of treaties and usages. In 1852, however, the Poll Tax Ordinance was passed to raise revenue for the administration of the newly created colony of the Gold Coast, independent of the British administration in Sierra Leone. ${ }^{82}$

Before the imposition of the Poll Tax, there is evidence of the collection of other kinds of taxes. The following colonial dispatch is instructive on this point.

\section{“Downing Street \\ $4^{\text {th }}$ August, 1855}

No. 3

"Sir,

I transmit to you herewith a letter from the Secretary to the Royal Commission of the Patriotic Fund, in acknowledgement of the sum of fifteen pounds eighteen shillings contributed by certain Residents on the Gold Coast to the Patriotic Fund and

\section{DOI: http://dx.doi.org/10.29322/IJSRP.8.4.2018.p7603}

${ }^{79}$ Bansah C. W. (2015) 'The Church and Cultural Ostracisation in Ghana'. Asian Journal Of Management Research, 6(2). DOI: http://ipublishing.co.in/ajmrvol1no1/volsix/EIJMRS6029.pdf

${ }^{80}$ Shaloff S. (1974) 'The Income Tax, Indirect Rule and the Depression: the Gold Coast Riots of 1931'. Cahiers d'Études Africaines, 14(54) pp. 359-375. DOI: https://doi.org/10.3406/cea.1974.2649

${ }^{81} \mathrm{Ibid}$; Native Treasury Ordinance of 1939

${ }^{82}$ Supra 28. p. 178 and 182; Poll Tax Ordinance of 1852 
conveying to them the thanks of the Royal Commissioners.

I have the honor to be Sir...

The Officer Administering

The Government of the Gold Coast" ${ }^{83}$

Among the various reasons for the introduction of Indirect Rule in British West Africa was the existence of an effective African tax system. Traditional rulers were the main instruments used in implementing this policy. Where there were no chiefs, "warrant chiefs" were created. These rulers assisted British colonial treasurers in collecting taxes from the people. British rule meant increased authority for chiefs to collect taxes and conversely the diminishing authority of the chiefs to impose taxes. The following communication between the Chief Registrar and the Secretary for Native Affairs concerning the attempted imposition of a tax by one chief on "refugees" living on his land expresses the point and makes for interesting reading:

\section{“COLONIAL SECRETARY'S OFFICE}

\section{ACCRA}

$26^{\text {th }}$ March, 1902.

Apontua,

I am directed to inform you that your letter, dated $15^{\text {th }}$ instant, in which you wrote to the Chief Justice about the action which the headman of Fancheneko was taking towards the Juabins residing at Domi, has been laid before the Governor who has caused a letter to be written to Headchief Amoako Ata II, of Akim Abuakwa, at Kibbi, directing him to inform Enin Ajaye that the proposed tax will not be allowed and that unless this chief refrains in future from troubling you and your people at Dome, he will be severely punished...

(Sgd) L. R. Arthur

Colonial Secretary

Kwabena Apontua,

OSEEM" $^{\prime 84}$

By 1908, authority to tax was clearly in the hands of the colonizing force and the following letter was written:

Domi

$6^{\text {th }}$ aug. 1908

${ }^{83}$ Gold Coast Despatches from Secretary of State to Governor 1855 (ADM1/1/13) Public Records and Archives Department, Accra.

${ }^{84}$ Ashanti Refugees and the People of Eastern Akim Case No. 145 (ADM 11/1/18), Public Records and Archival Department.
Sir,

I beg most respectfully to lay this before your Honour that, about six years ago, the late Chief Anin Adjaye of Fancheneko was claiming from me and my subjects a proposed tax which I refused to pay and also I complained to Government about same. Your Honor the present Chief RamRam who has now occupied the throne, has commenced of giving me and my people trouble by raising a tax of load of cocoa from each of us (Juabins) at the expiration of every year and if I and my people refuse to pay this tax, we must quit from this land (Domi) and as I have a paper on this same case, from Government and all the time like to live with each other in peace, I have therefore dispatched a bearer by name Quacoo Nyame to come with this my letter...

I have the honour to be sir

Your most obedient servant

Chief Kwabena Apontua

$(\mathrm{Sgd})^{85}$

After independence in 1957, the Government of Ghana began an accelerated socio-economic development plan and so there was the urgent need for the government to raise enough tax revenue to finance the program. However, attempts at revenue mobilization were hampered by factors such as the existence of over 300 State Enterprises which had monopolized business activities in critical sectors of the economy, but had been exempted from paying tax on their profits by the statutes that established them. Where they applied, tax rates were very high, almost punitive, and therefore encouraged considerable evasion. ${ }^{86}$. There were many small and medium scale enterprises and self-employed professionals who were not registered and did not pay taxes at all, and of course a large informal sector from which it was difficult to extract taxes. The final dressing was a weak system of tax administration. The most important tax bases for revenue generation was therefore confined to the profits of a relatively small highly organized formal sector, usually multinationals, and the wages and salaries of the civil service. Thus, tax revenues were inadequate for the development list agenda of the government.

The situation further created high fiscal deficits and macroeconomic instability for the country. Many attempts were made to raise additional tax revenue. However, mechanisms such as presumptive taxation, standard assessments, and the insistence on the production of Tax Clearance Certificates for certain business and non-business transactions (and other

${ }^{85}$ Ibid.

${ }^{86}$ Aboagye, P. Y. \& Hillbom, E. (2020) 'Tax Bargaining, Fiscal Contracts, and Fiscal Capacity in Ghana: A Long-Term Perspective'. African Affairs 119(475), pp. 177-202. DOI: https://doi.org/10.1093/afraf/adaa004 p. 195-196 
attempts at enhancing horizontal and vertical equity by facilitating the taxation of self-employed professionals and businesses and informal small-scale business operators) run into problems as a result of weak administrative structures. Macroeconomic instability continued. ${ }^{87}$

In 1983, Ghana adopted the Structural Adjustment Program, which saw a major shake-up in Ghana's tax administration in 1986. Among the structural changes were the setting up of Departments for Research, Planning and Monitoring, Legal, Audit, and Finance and Administration to handle specific functions at the Internal Revenue Service (IRS), the establishment of the Customs, Excise and Preventive Service and finally, the establishment of a Value Added Tax Service. The policy objectives of the administrative changes included among others:

- Identifying and researching into potential areas of taxation, especially in the informal sector which had hitherto been hard-to-tax;

- Re-demarcating tax administrative jurisdiction with a view to bringing taxation closer to the doorstep of the taxpayer;

- Decentralization of operational activities to increase tax administrator-taxpayer contacts and enhance taxpayer identification, especially in the informal sector; and

- Reviewing policies that address problems of compliance by the self-employed and informal sector to increase government tax revenue and broaden the tax base. ${ }^{88}$

General government policies continue to drive businesses into the informal sector and underground, and the possible conflicts between policy goals to support small business development and the policy goal to broaden the tax base and reduce underground economic activities were not carefully thought through. Today, we still have a sufficiently narrow tax base, a less than efficient tax administration system and huge taxpayer dissatisfaction. ${ }^{89}$

The beginning of the 21st century saw some major changes by modern governments in a bid to improve the tax administration system: the creation of institutions like the Chartered Institute of Taxation in 2016 and especially the Ghana Revenue Authority (GRA), formed in 2009. The former was created to promote the study of taxation and to regulate the practice of taxation in Ghana. ${ }^{90}$ The GRA, which brought a more structural change to the system, had as its functions to:

\footnotetext{
${ }^{87}$ Ibid p. 196

${ }^{88}$ World Bank (2005) 'Tax Compliance and the Informal Sector in Ghana.' A Report by the World Bank Organisation. (on file with author)

${ }^{89}$ This is probably why the Revenue Administration (Amendment) Act, 2020 (Act 1029) was passed on 6 October 2020. The Act makes provision for tax payers who are dissatisfied with tax decisions to seek redress, and even goes on to create an Independent Tax Appeals Board under the Act.

${ }^{90}$ See http:/ / www.taxghana.org/ [Accessed on 31 ${ }^{\text {st }}$ July 2017]
}

- Integrate the Internal Revenue Service (IRS) and the Value Added Tax Service (VATS) into domestic tax operations on functional lines;

- Integrate the management of Domestic Tax and Customs; and

- Modernize Domestic Tax and Customs operations through the review of processes and procedures with ICT as the backbone. ${ }^{91}$

The creation of these bodies may have made tax mobilization in Ghana slightly more organized. However, there is still a lot to be done to improve the overall system.

\section{TAX LAWS ${ }^{92}$}

The Constitution of Ghana provides in Article 174 that no taxation shall be imposed otherwise than by or under the authority of an Act of Parliament. And where an Act confers power on any person or authority to waive or vary a tax imposed by that Act, the exercise of the power of waiver or variation shall be subject to the prior approval of Parliament.

Until recently, three revenue agencies, operating under three different laws, administered the main part of Ghana's central government revenue. These were the Internal Revenue Service, the Customs, Excise and Preventive Service and the Value Added Tax Service. ${ }^{93}$ Currently, these three agencies work under the umbrella of the Ghana Revenue Authority, created by an Act of Parliament in 2009. Thus, the GRA oversees these three and is the state body responsible for the administration of taxes and tax related matters. Monies collected from all three sources are paid into the Consolidated Fund.

There is a firm constitutional basis for transparency and the demand for customer satisfaction in tax administration. The general human rights provisions in the 1992 Constitution of Ghana and especially Articles 18 and 20 (on the security of personal property and Article 23 (a charge on administrative bodies such as tax institutions; and administrative officials such as tax administrators to "act fairly and reasonably and comply with the requirements imposed on them by law")) bear directly on the tax system. Article 23 further provides that "persons aggrieved by the exercise of such acts and decisions shall have the right to seek redress before a court or tribunal". To add substance to this right to administrative justice, Article 33 of the Constitution provides that anybody may apply to the High Court for redress in the case of violation of any of the

${ }^{91}$ See http://www.gra.gov.gh/index.php/about-us [Accessed on 31st July 2017]

${ }^{92}$ This section borrows from: Jakalia J. \& Kolberg D. (unpublished) 'Ghanaian Procedural Tax Law'. Unpublished paper. (On file with the author)

${ }^{93}$ As created under the Internal Revenue Service Act, 1986 (P.N.D.C.L. 143), the Customs, Excise and Preventive Service (Management) Act 1993 (P.N.D.C.L. 330) and the Value Added Tax Act, 1998 (Act 546) respectively. 
fundamental human rights. An appeal from the decision of the High Court lies to the Court of Appeal and then the Supreme Court.

In apparent response to these constitutional injunctions, Ghana's tax legislation has provisions on assessments, collection and enforcements. Under the Revenue Administration Act, 2016 (Act 915) ${ }^{94}$, a person who is dissatisfied with a tax decision that directly affects that person may lodge an objection to the decision with the Commissioner-General within thirty days of being notified of the tax decision. ${ }^{95}$ Although the provision in the preceding sentence appears to provide taxpayers the opportunity to seek redress for tax assessments which are not in consonance with the tax laws, aggrieved taxpayers are required to pay a deposit before they can be given a hearing. ${ }^{96}$ The Commissioner-General is given the discretionary power to waive, vary or suspend the payment of the deposit pending the determination of the objection or take any other action that the CommissionerGeneral considers appropriate including the deposit of security. However, this may provide little comfort to the taxpayer since it would be an uphill task to get the Commissioner-General to exercise this discretion in favor of a taxpayer. ${ }^{97}$

The High Court (Civil Procedure Rules) 2004 (C.I. 47) also contain rules that apply to court proceedings that relate to any tax disputes. The Civil Procedure Rules provide regulations for tax appeals and establish Commercial Courts. Under Order 54 of the Rules (on Tax Appeals against the Commissioner-General with respect to objections to tax decisions and assessments ${ }^{98}$ ), a person can appeal to the court by filing the particulars of the appeal with the Court Registrar.

The law provides that an appellant shall, pending the determination of the appeal, pay an amount not less than quarter of the amount payable in the first quarter of that year of assessment as contained in the notice of the assessment and the appeal shall not be entertained unless the Appellant complied with the requirement of paying the deposit. ${ }^{99}$ A High Court has ruled that it would be unfair to require that a taxpayer pays a deposit before an objection can be filed with the Commissioner-General and also pay an amount not less than quarter of the amount payable in the first quarter of that year of assessment, pending the determination of the appeal. ${ }^{100}$ Thus, if there is evidence that a taxpayer paid the deposit at the time of filing an objection with the Commissioner-General, the

\footnotetext{
${ }^{94}$ The long title to the Act states that it is to provide for the administration and collection of revenue by the Ghana Revenue Authority and for related matters.

${ }^{95}$ Section $42(1)$ of Act 915.

${ }^{96}$ Section $42(5)$ of Act 915 provides that a tax decision shall not be entertained unless the person has in the case of import duties and taxes, paid all outstanding taxes including the full amount of the tax in dispute; and in the case of other taxes, paid all outstanding taxes including thirty percent of the tax in dispute.

${ }^{97}$ Section 42(6) of Act 915.
}

taxpayer is not required to pay an additional amount pending the determination of tax appeal before the court. ${ }^{101}$ The court may take evidence or seek experts' assistance and may confirm, reduce, increase or annul an assessment on which the decision is based, and may in all cases take such decision as the court considers appropriate.

Under Order 58 (on Commercial Courts), tax matters are listed as one of the claims that can be brought to the Commercial Court. Rule 3 of Order 58 states that actions in the Commercial Courts shall be commenced and regulated in the same way as actions in the High Court. Consequently, the rules on filing of the writ of summons, entry of appearance, defense and reply shall apply to actions in the Commercial Courts. Upon filing of a reply by the Commissioner on an appeal to his decision, the Administrator of the Commercial Court shall assign the case to a judge of the court to conduct a pre-trial settlement conference. The parties may be represented by their counsel, and experts may be invited to assist.

However, if at this stage the parties wish to settle the matter by other means like arbitration, negotiation or mediation, the judge shall give time and terms for settlement. Where a settlement is reached amicably, it shall be read to parties and entered as the judgment of the court. Where the pre-trial conference or the attempt at out of court settlement fails, the pre-trial judge shall direct the case to the Administrator to be fixed before another judge for trial.

Under Order 58, Rule 10, the judge shall try the case with the help of two assessors. Rule 12 provides that after the case has been heard, the court shall sum up the evidence for each side and then require each assessor to state his opinion in writing as to the case with regards to the facts and the judge shall pronounce judgment on the case. Opinions of the assessors are not binding on the court.

In effect, under the High Court Civil Procedure Rules, a tax case may be settled in court either through the pre-trial conference or through a normal trial. If the parties choose to settle the matter with an external person or body, they can come back to the court afterwards and have the award or settlement entered as a court judgment.

Only a few cases on tax matters are heard in Ghana. The reason for this is the relative cost of litigation, delays in the court system and the reluctance of Ghanaians to litigate with the government.

\footnotetext{
${ }^{98}$ Revenue Administration (Amendment) Act, 2020 (Act 1029): Section 1 (Section 44 of Act 915 amended).

${ }^{99}$ Order 54 Rule 4 (1) and (2) of C.I. 47

100 Fan Milk Limited v Commissioner-General, Ghana Revenue Authority HC. Suit No. CM/TAX/004/18

${ }^{101}$ The Court of Appeal in the case of Beiersdorf Ghana Limited $v$ the Commissioner-General, Ghana Revenue Authority. Suit No. $\mathrm{H} 1 / 140 / 2019$ reasoned that there is no hard and fast rule about the payment of the quarter of the tax assessed.
} 
A total of 961 out of 1002 individual taxpayers we interviewed responded that they thought tax evasion was a crime. Only 9 thought it was acceptable misconduct. Aside this, almost all respondents, including the very highly informed and educated, knew next to nothing about tax laws.

\section{TAX INFORMATION}

Findings on tax information were at different levels. First, there is limited information about tax laws and the tax liability of individuals and firms. Next, there is limited information on tax reliefs such as tax deductions, tax exemptions, tax rebates, tax holidays and the like. Finally, there is limited information on the uses to which tax revenues are put.

There is generally very little information about tax in the public domain. People are unable to distinguish between different types of taxes and between taxes and other forms of revenue generation such as fees. Others even conflate taxes with payments for refuse and garbage services; and local level and national level taxation are all seen as the same.

One of our field staff reported this from the Ashanti Region: "My interaction here took me to mostly young adults who are either learning a trade like hair plaiting or car washing. Generally, I observed that most young person's knew little or nothing at all about taxation..." And in the absence of information there is misinformation. Most people feel that taxes are used to enrich the lives of government officials to the detriment of the poor taxpayer.

Ghanaians have a lot of questions for the tax administration:

- Who is responsible for giving relevant information to the taxpayer?

- How does the taxpayer access information pertaining to his tax issues?

- Is there any form of regular sensitization and education on tax issues for the taxpayer?

- Are tax defaulters prosecuted?

- How is the taxpayer's money used?

- Does the taxpayer have a say in what the tax money should be used for; are his views taken into consideration?

- Is corruption among tax officials a perception or reality?

- $\quad$ Are corrupt tax officials punished?

It is clear that mechanisms for improving information flow between tax administrators and taxpayers are essential.

102 Centre for Policy Analysis (CEPA) (2005) 'State Audit: An Instrument for Accountability and Good Economic Governance'. Ghana: Selected Economic Issues No. 10, p.1.

${ }^{103}$ See www.gra.gov.gh [Accessed on $10^{\text {th }}$ December 2020]

${ }^{104}$ Kemp S. (2020), 'Digital 2020: Ghana'. Data Reportal, February 2020.

Available at https://datareportal.com/reports/digital-2020-ghana

[Accessed on 12th December 2020]
"The people's right to know and even control how their taxes and other resources made available to the government are used is one of the cornerstones of democratic governance." ${ }^{102}$

Years after the creation of the Ghana Revenue Authority (GRA), the organization has tried to ensure that most basic information on the taxation system can be found on their website. ${ }^{103}$ Notwithstanding this, internet access in Ghana is available to only $48 \%$ of the population, and generally at very low speed ${ }^{104}$. Where access is not hindered, the average Ghanaian is confronted with difficulty in comprehending dense tax laws. True, organizations like PwC Ghana of PricewaterhouseCoopers International Limited, PKF Ghana and KPMG Ghana provide services that include publishing tax information on their websites and to their clients, ${ }^{105}$ but the services of these firms are pretty expensive and beyond the means of the average taxpayer and the information they publish on their websites, still pretty dense for the ordinary person.

\section{TAX EDUCATION}

Tax education is so germane to the concept of taxation that it is sometimes conflated with tax culture. Some experts actually define tax culture as "the removal of the general public's 'tax illiteracy'" and in this sense tax culture is considered to be the opposite of "tax illiteracy". ${ }^{106}$

As noted earlier, most people, especially in the formal sector, do not know much about the tax system and the filing and payment processes. Our field researchers had to explain every single question to virtually all respondents several times, backed up by mini-educational sessions on the system of taxation in Ghana. A lot of the questionnaires that were left to be filled by some category of formal sector workers were not properly filled; the reason was that they did not understand the tax system enough to fill out the questionnaires by themselves. This calls for tax education not just tax information. Those in the informal sector ordinarily tender their sales returns and they are told how much to pay by the taxman. They then proceed to pay for it. They sometimes get a receipt but they are unable to distinguish genuine receipts from fake ones. They are not even able to identify for sure that a taxman is indeed a taxman. Many have been duped several times. Consequently, a number of respondents complained that the tax system was not transparent but did not know enough of its workings to make suggestions for improvement.

105 See https://home.kpmg.com/gh/en/home/about.html
[Accessed on 25th August 2017]; see also
http://www.pkf.com/publications/tax-guides/ghana-tax-guide/
[Accessed on 2017]; $25^{\text {th }}$ August 2 and see
https://www.pwc.com/gh/en/ [Accessed on 25 $5^{\text {th }}$ August 2017]
106 Supra 21.p. 6-7.


Another extract from the journal of a research assistant is very instructive on this point: "As regards general knowledge of taxation, interviewees knew next to nothing about taxation. They paid money without knowing to which officials they were paying the money and what kind of tax obligations they were fulfilling. This further slowed things down as I had to explain what I meant by taxes and which particular payments were taxes. Most students did not appreciate the taxation process... Only a handful appreciated indirect forms of taxation such as the VAT and the NHIL."

In the words of one intelligent observer we met in the field: "Taxation without Education is Hallucination". And the absence of education is fodder for misinformation. During field research, a lot of interviewees thought that government officials and chiefs did not pay taxes. People were generally unaware of tax exemptions and tax rebates. In the results of the large taxpayers' survey, $66 \%$ want to be provided with more specific information. ${ }^{107}$

Today, Ghanaians remain very uneducated about their system of taxation. Some do not know the tax rates or amount of taxes they are to pay, the type of taxes they are paying, or even what exactly their monies are being used for. In other words, most citizens pay blindly, and this may be encouraging corruption by taxmen as many taxpayers do not know enough about taxation to question the demands of the taxman. A tax consultant has the last words on this matter: "The level of tax education and awareness is insufficient. This is reflected in the low level of voluntary compliance by taxpayers and reluctance to file returns." 108

Much has been said over and over again by authority figures in the country about the need for vigorous tax education nationwide, but there seems to have been no action to follow the words; and the little that is being done is woefully inadequate. Nii Ayi Aryeetey, President of the Chartered Institute of Taxation Ghana, admitted this when in July 2016 he said, "...there was more education to be done since some of the populace were still not abreast with the tax laws". ${ }^{109} \mathrm{Mr}$ Seth Terkper, a former Minister of

${ }^{107}$ Ghana Revenue Authority \& German Technical Cooperation (2004) Large Taxpayers Union Survey. German Technical Cooperation (GTZ)

${ }^{108}$ Asante R. K. (2000) 'Ghana Revenue Agencies Reform ProjectConsultancy Assignment Revenue Agency Reform.' Prepared by Richard Kwame Asante of Kwame Asante E Associates, June 2000. (On file with author) p.10.

https://www.ghanabusinessnews.com/2016/07/14/governmenturged-to-intensify-tax-education/ [Accessed on 24 ${ }^{\text {th }}$ August 2017]

${ }^{110}$ Ghana News Agency (2013) 'Finance Minister Calls For Sustained Tax Education'. PeaceFm Online, 5 ${ }^{\text {th }}$ April 2013. Available at https://www.peacefmonline.com/pages/business/news/201304/1 60298.php [Accessed on 15th December 2020]

${ }^{111}$ ATL Fm Online (2017) 'Medium Taxpayer Office Organises Tax Education Seminar'. ATL Fm Online, $4^{\text {th }}$ August 2017. Available at http://www.atlfmonline.com/home/11-campus-news/2632-capecoast-medium-taxpayer-office-organizes-tax-education-
Finance, also asked for aggressive and sustained public education for taxpayers in the informal sector to become tax compliant. In his words, it is "pertinent for tax managers to adopt practical measures to bring operators in the informal sector, the worst offenders of tax evasion, into the net and plug all loopholes to prevent leakages in the system", after stressing that this informal sector makes up about $70 \%$ of the Ghanaian economy. ${ }^{110}$

It would be remiss not to add that the GRA has tried to improve tax education by organizing regular Tax Education Seminars for Large, Medium and Small (including informal sector) Taxpayers ${ }^{111}$. This is a good step but it unfortunately does not address the broad majority of ordinary taxpayers. The GRA may also have to revise their strategy and understand that seminars are not the only answer to the problem.

\section{TAX MOBILISATION}

The mobilization of tax revenue is a key policy objective. One of the ways in which the state may maximize resources it extracts from taxpayers is through diversification of the tax revenue base. Physical and political limits on tax rates encourage the state to diversify the tax base so as to maximize revenues. The taxmaximizing state will therefore have a clear incentive to distribute its tax collections so as to exceed the revenuemaximizing rate on any given tax base. However, tax diversification is no help to the developing country that does not have the administrative capacity to exploit the tax base fully. Tax diversification has no independent influence on the tax revenues of developing countries. ${ }^{112}$. Apparently, a state must reach some threshold level of administrative capacity (as measured by per capita income) before it can reap the benefits of tax diversification. For this reason, ordinarily, countries with more diversified tax bases collect more revenue relative to national income. ${ }^{113}$ In the case of developing countries, however, although they may have a more diversified tax base than developed countries, they are unable to exploit it because of administrative weaknesses. ${ }^{114}$

seminar.html.html [Accessed on 9th July 2018]; Ghana News Agency (2017) 'GRA Holds Tax Education Seminar For Small Taxpayers in Cape Coast'. GhanaWeb, 11 ${ }^{\text {th }}$ August 2017. Available at https://www.ghanaweb.com/GhanaHomePage/business/GRA-

holds-tax-education-seminar-for-small-taxpayers-in-Cape-Coast-

568487 [Accessed on 10th July 2018]; Ghana News Agency (2013) 'GRA holds Seminar on Transfer Pricing for Large Tax Payers'. Business Ghana, 24 ${ }^{\text {th }}$ February, 2013. Available at http://www.businessghana.com/site/news/business/101169/legal [Accessed on 10th July 2018]

${ }^{112}$ Conybeare J. A. (1982) 'The Rent-Seeking State and Revenue Diversification', World Politics, 35(1), pp. 25-42.

${ }^{113}$ Ibid. p. 40

${ }^{114}$ Ibid. p. 36; Lotz J. R. \& Morss E. R. A. (1970) 'Theory of Tax Level Determinants for Developing Countries'. Economic Development and Cultural Change 18(3). p. 338 
Tax mobilization is recognized as an essential issue in Ghana. In fact, the theme for the Fourth Quadrennial National Delegates' Conference of the IRS division of the Public Services Workers Union (PSWU) was "Sustaining the Growth and Development of the Economy of Ghana through Direct Tax Mobilization, The Role of Labor"115. It was noted at this conference that tax administration has become extremely important both to those concerned with increased tax yields and those concerned with tax policy and its effects on the economy in general. It was also noted that direct tax collection is "very difficult and cumbersome".

In the 2006 budget statement, the government of Ghana proposed to waive tax penalties in order to effectively mobilize huge arrears of taxes and widen the tax net. A little later, the Ministry of Finance and Economic Planning provided an opportunity to all corporate bodies and individuals who were in default of their income tax obligations to clear them without any penalty or sanction. ${ }^{116}$ The industry welcomed this move the very next day after it was brought into effect, calling for regularization of the process of granting tax amnesties and for government to endeavor to widen the tax net to cover the informal sector. ${ }^{117}$ A similar strategy was used in 2012 when government offered tax evaders the opportunity to come clean and start paying their taxes again, in exchange for protection from interest and penalties. This was in a bid to stop tax evasion while maximizing tax mobilization for the year; ${ }^{118}$ same was done in 2017. ${ }^{119}$ Another attempt was made last year to encourage voluntary tax disclosures by an amendment to the Revenue Administration Act to waive penalties for taxpayers who voluntarily disclose their tax activities to the Ghana Revenue Authority. ${ }^{120}$ It is clear that many potential taxpayers are outside the tax net and even those within the net do not fully meet their tax obligations.

The wide divergence between the tax revenues collected and potential tax revenues that can be collected in many African countries indicates that there is scope for raising tax revenue without increasing tax rates by reinforcing tax and customs administration, reducing tax exemptions and fighting fraud and corruption. Despite these reinforcement mechanisms, one must be realistic in terms of improvement in revenue ratios that can be reasonably expected to be achieved in many African countries given

\footnotetext{
${ }^{115}$ DPADM/UNDESA (2004) 'Governance World Watch', Compiled and edited by the Knowledge Management Branch of DPADM/UNDESA, Issue 67, November 2004

${ }^{116}$ Yeboah E. K. (2006) 'Tax Amnesty for All'. Daily Graphic, 12 January 2006, p. 1-3

${ }^{117}$ Yeboah E. K. (2006) 'Captains of Industry Welcome Tax Amnesty'. Daily Graphic, 13 January 2006. p. 16

${ }^{118}$ MyJoyOnline (2012) 'Ghana Revenue Authority offers temporary amnesty to tax evaders'. MyJoyOnline, 31 October 2012. Available at https://www.myjoyonline.com/ghana-revenue-authority-offerstemporary-amnesty-to-tax-evaders/
}

the low level of development and the heavily agricultural and informal character of their economies. ${ }^{121}$

In consequence of the above, African countries have introduced VAT because it is recognized as a modern and efficient way to collect the revenue needed for their countries. For example, many African countries chose a unique rate for VAT. This was dictated by the heavy administrative costs of having a VAT at several rates. Basic needs and the social services (education and health) are often exempted from VAT in such a way as to limit the regressive impact of a priori single rate. The purpose of applying a single rate is to improve the efficiency of taxation by facilitating its administrative management and by limiting the possibilities of evasion. A multiplicity of taxation rates would lead to serious administrative and control costs. Thus, in terms of the structure of taxation, the role of indirect taxation has become increasingly important in Africa, while that of personal income and other taxes remain very insignificant. ${ }^{122}$

Aside the Ghana Revenue Authority which administers income tax, customs and excise duties and VAT, the local authorities, called District Assemblies, are the fourth most important tax agency. When we asked the chiefs about the agency for tax mobilization in their areas of jurisdiction, 25 of the 33 responses were "the District Assembly". Article 245 of the 1992 Constitution of Ghana under the topic of "Decentralization and Local Government" states that the functions of the District Assemblies include the levying and collection of taxes, rates, duties and fees.

Under the local government laws, each District Assembly must submit, through the Regional Co-ordinating Council, the development plans of the district to the National Development Planning Commission (NDPC) for approval. They then submit their budget related to the approved plans to the Minister for Finance for approval. Aside the District Assemblies Common Fund (at least 5\% of government revenue that is constitutionally required to be transferred by central government to the districts) and donor funds, the districts generate revenue through the imposition of rates. Rates may be "general" or "special". A "general rate" means a rate made and levied over the whole district for the general purposes of the district and a "special rate" means a rate made and levied over a specified area in the district for the purpose of a specified project in the district approved by the district assembly for

${ }^{119}$ Mensah B. (Ghana News Agency) (2017) 'Ghana Government To Grant Tax Amnesty For The Next 8 Months'. Modern Ghana, 25 December 2017. Available at https://www.modernghana.com/news/824866/ghanagovernment-to-grant-tax-amnesty-for-the-next.html [Accessed on 12th December 2020].

${ }^{120}$ Revenue Administration (Amendment) Act, 2020 (Act 1029)

121 Supra 12. p.1-3.

122 Supra 12. 
that area. ${ }^{123}$ General rates include rates payable by the owner of premises within the district, rates assessed on possessions, rates assessed on persons who reside within the area and rates assessed on owners of movable and immovable property in the area. ${ }^{124}$

Under the Local Government Act, 2016, a district assembly may in writing authorize any suitable person in respect of a specified area of the district as a "Rate Collector" to collect rates. A Rate Collector is mandated to furnish in writing to the district assembly a nominal roll of all rateable persons in the area in respect of which he has been authorized to collect rates. He must collect all rates and pay the amount received to the District Assembly and report any person who fails to pay the amount due. ${ }^{125}$

The key problem with tax mobilization in Ghana appears to be poor revenue collection mechanisms. There are no proper databases of taxable persons, property or other possessions. It is therefore very difficult to mobilize taxes from outside the formal sector. As a result, there are serious shortfalls in tax mobilization in Ghana. This is why the Ghana Revenue Authority in 2012 decided to improve its operations across the country in an effort to boost its integration and modernization process. Taxpayers were grouped into small, medium or large categories according to their annual turnover. ${ }^{126}$

The creation of the Special Revenue Mobilization Task Force in 2016, with the aim to strengthen the revenue collection regime and enforce compliance with tax laws, was also to improve tax mobilization. ${ }^{127}$ In the same year, there was also the introduction of a database software, the Total Revenue Integrated Processing System (TRIPS), which the GRA admitted helped boost tax mobilization in the country. The software is for managing databases and for controlling and administering revenue as well as tax payment processing. ${ }^{128}$ These were all efforts to help pull in revenue from every type of business and avoid tax leakages.

The field research also revealed that private sector employers often leave their employees to their own tax obligations. A mechanism of taxation that ensures that private sector employers regularly deduct the taxes of their employees at source will enhance revenue collection. The $70 \%$ of respondents who did not respond to the question

${ }^{123}$ Section 234 and Section 146(3) of the Local Government Act, 2016 (Act 936)

${ }^{124}$ Section 146(2) of the Local Government Act, 2016 (Act 936)

${ }^{125}$ Sections 148, 161, 162, 166 and 169 of the Local Government Act, 2016 (Act 936)

${ }^{126}$ Business World (2012) ‘GRA To Group Taxpayer Offices'. Business World, 3 October 2012. Available at http://www.businessworldghana.com/gra-to-group-taxpayeroffices/ [Accessed 12 $2^{\text {th }}$ July 2017]

${ }^{127}$ Ghana News Agency (2015) 'GRA Inaugurates Special Taskforce'. Modern Ghana, 3 August 2015. Available at https://www.modernghana.com/news/633973/ghana-revenueauthority-inaugurates-special-taskfo.html [Accessed 12 ${ }^{\text {th }}$ July 2017];

Kale-Dery S. \& Agbenorsi J. (2019) 'GRA inaugurates 'Operation Collect, Name and Shame' Task Force'. Graphic Online, 5 September of paying taxes for employees marks a significant proportion of employers who do not pay taxes on behalf of their employees. This is so even if we correct for those respondents who are not employers. Of the remaining 30\% who are employers, only $8 \%$ pay taxes on behalf of their employees.

\section{TAX TRANSPARENCY}

The transparency of a tax system is directly related to people's willingness to pay taxes and consequently, the amount of taxes that may be mobilized. From our interviews, a chief reason why many do not like to pay taxes is that the tax system is not transparent enough. Out of 1002 respondents, 781 disagreed or strongly disagreed with the assertion that the Ghanaian tax system is transparent. A modern tax system should ensure collection on the basis of known, clear, transparent and contestable rules. It should also provide mechanisms for citizen monitoring of revenue collected and how such revenue is disbursed for even national development.

Good governance consists of several dimensions: the capacity of the state to function in the service of the public good, commitment to the public good, transparency, accountability, the rule of law, and mechanisms for dispute resolution form part of these. "Most Ghanaians consider transparency and accountability, the rule of law and free and fair elections...to be the key components of good governance", ${ }^{129}$ and the second Ghana Shared Growth and Development Agenda provides that one of the actions to be taken to achieve good governance is "improving transparency and accountability in the management and use of public funds and other national resources"130

By transparency, we mean the openness of state business and conduct to the scrutiny of other state actors and of the public. Transparency requires freedom of information and mechanisms to ensure that citizens can acquire information about how government makes decisions, conducts business and spends public money. Transparency requires full openness, including openness with regard to the personal finances of government

2019. Available at https://www.graphic.com.gh/news/generalnews/gra-inaugurates-operation-collect-name-and-shame-taskforce.html [Accessed on 11th December 2020]

${ }^{128}$ Ghanaian Times (2016) 'Database Software Shoots Up GRA Tax Mobilisation'. Business Ghana, 12 ${ }^{\text {th }}$ December 2016. Available at https://www.businessghana.com/site/news/business/138852/Dat abase-software-shoots-up-GRA-tax-mobilisation [Accessed on $12^{\text {th }}$ July 2017]

${ }^{129}$ Supra 58. p. 4.

${ }^{130}$ National Development Planning Commission (NDPC), (2014). Ghana Shared Growth and Development Agenda (GSGDA II) (2014 - 2017) Vol 1: Policy Framework. Accra, Ghana. December 2014. 
officials. ${ }^{131}$ From our interviews, Ghanaians are yearning to know exactly how their tax revenues are being used.

Transparency is intimately related to accountability. Governing agents are more likely to be responsible and "good" when they are answerable to the society for their conduct in general and to other specific institutions that monitor their behavior and can impose sanctions upon them. Effective oversight requires open flows of information (transparency) so that monitors can discover facts and mobilize evidence. This requires a system of government in which different institutions check and hold one another accountable, compelling them to justify their actions. Power is thus constrained, bound not only by "legal constraints but also by the logic of public reasoning." ${ }^{132}$ A manifest commitment to the public welfare on the part of government also breeds a civic spirit in society, including a willingness to pay taxes and obey the law. Ordinary citizens will sacrifice immediate advantages for the longer-term common good only when they believe that their fellow citizens will as well. "When government itself is transparent and disciplined in its commitment to the public good, it provides credible signals to the rest of society about what types of behaviors can be expected. A more capable and knowledgeable government also generates the capacity to enforce the law, mediate disputes, keep order, collect taxes, promote trade, maintain fiscal stability, attract investment, and so foster economic growth." 133 When we think transparency, we should think, "What would inspire Ghanaians to want to pay their taxes, and to identify with such an exciting national project?"134

The tenets of tax transparency are effectively captured in the following quotation: "The people's right to know and even control how their taxes and other resources made available to the government are used, is one of the cornerstones of democratic government...Government therefore has a special responsibility to provide assurances to the public a clear picture of where public finances [including taxes] come from, how utilized and accounted for in an open and credible framework ${ }^{\prime 135}$. The framework for this, in the case of tax revenues, is very unclear to the common woman to say the least.

The transparency issues relating to taxation have historical roots. The system of taxation in pre-colonial Ghana was not very transparent. Payment of taxes was borne more out of the reverence and trust the citizenry had for their chiefs than the transparency of the tax system. In the words of a leading chief in Ghana today, the share of royalties that

131 Diamond L. (2005) 'Democracy, Development and Good Governance: the inseparable links'. Ghana Centre for Democratic Development (CDD-Ghana) Kronti ne Akwamu. Series No. 1, pp. 6-9.

${ }^{132}$ Ibid. p. 9.

${ }^{133}$ Ibid. p. 17.

${ }^{134}$ Ibid. p. 17. goes to the stool should be given to the chief as the occupant of the stool and be regarded as "unaccountable imprest". This exemplifies the transparency issues that have historical roots. The system of taxation during colonial rule was even more opaque. Citizens were hardly consulted on what, when and how revenues may be mobilized and utilized. However, there are processes of transparency and accountability we can learn from our traditional system of revenue generation. In the past, "unaccountable imprest" was actually accountable. This is because the chief, as chief, was the automatic bearer of certain financial obligations of the whole community. Thus, if a stranger came into town it was the duty of the chief to feed, clothe and house him and generally deal with his issues. The so-called "unaccountable imprest" was directed to such community ends, and the community was glad and not provoked because the obligations of the chief frequently exceeded the quantum of the unaccountable imprest. In some communities, this circumstance still exists. In others, however, chiefs take the benefit of the unaccountable imprest and neglect the obligations that come with it. This has raised serious issues of transparency and accountability.

In post independent Ghana, issues of transparency in the tax system still persist. The World Bank reported that the 1992 fiscal shock in Ghana was in part caused by the decision to write-off huge taxes owed by the GNPC ${ }^{\prime 136}$ The Council on Indigenous Business Associations (CIBA) appeared to have acted as a major conduit for the collection of taxes from the public under the administration of the National Democratic Congress (NDC) party between 1992 and 1996. As consideration, the government provided material pay-offs to the leaders and employees of those associated organizations which were granted the right to collect taxes from their members on behalf of the Internal Revenue Service and a municipal authority in exchange for a commission. In the past, CIBA has also collected rates in Kumasi on behalf of the Kumasi Metropolitan Assembly, for which it received a ten per cent commission. Such "taxfarming" created jobs for supporters of the party in government as well as substantial revenues for compliant associations. $^{137}$

Lack of transparency is an issue at several other micro levels: What taxes am I supposed to pay? To whom do I pay them? How am I assessed? Can I challenge the assessment? Where do I go to make such a challenge? What will the money be used for and how will I know that it is beneficial to me, my sister, the community, or the public? One trader held out various receipts to one of our research

\footnotetext{
${ }^{135}$ Supra 46. pp.1-2.

${ }^{136}$ Sandbrook R. \& Oelbaum J. (1997) 'Reforming Dysfunctional Institutions through Democratisation? Reflections on Ghana'. The Journal of Modern African Studies, 35(4). pp 603-646. p 629.

${ }^{137}$ Ibid. p. 625-6.
} 
associates and asked how she was supposed to know that they were genuine, that she gave the money to the right person, and that the money would arrive in government coffers and be used for something useful.

Today, it seems nobody knows what type of taxes are collected, how they are used and how beneficial tax revenues are. In the words of a number of respondents: "No, I don't know anything about the tax system so I do not know if it is transparent." "The government should say exactly what the money is being used for and there should be public education [on taxation]". One of our field staff for the Ashanti Region made the following observation: "People told me about tax collectors and gave the recommendation to "change them all'". They claimed that some of the collectors keep part of the money. Even very well educated and informed chiefs did not know who raises revenue within their jurisdictions and what percentage of such revenues benefit the communities from which the monies are taken. More people explained that due to the cultural phenomenon in African countries where everyone is "related", the revenue agency should employ collectors born in other districts, should move them after a certain period of time to another district and take care in choosing "good people".

Our respondents had a number of suggestions for improving transparency in the tax system in Ghana: tax rebate and tax relief information and forms should be readily available; the public should be educated in order to understand the workings of the tax system so they can challenge wrongdoing and sub-optimal performance; tax returns should be published; tax administrators should listen to the issues of taxpayers and attend to them; mechanisms should be instituted to make those who use tax revenues accountable to the public; persons involved in corruption related to taxation must be prosecuted - not just dismissed from their jobs; bureaucracy should be eliminated in the system of tax administration; and the relative power of the citizen as against the tax authorities should be increased.

In the words of one respondent, "those who know what taxes are used for would always want to pay." "Why would you not want to pay tax to the government?" and "Because I do not know what the tax money is used for" was common dialogue between our field staff and respondents. When people do not know what taxes are used for, they will guess what it is used for and orient their actions and attitudes accordingly.

In the Large Taxpayers Unit (LTU) survey ${ }^{138}$, most respondents felt strongly about how taxes are used; mainly that it is used to enrich the lives of government officials to the detriment of the poor taxpayer. They thought that Government should account for its use of the money. Many of our respondents did not know much about the tax system and thought that the tax system was not transparent at all. They would prefer to give money to charity rather than pay taxes. They also feel that they should have a say in the way tax is administered and be capable of assessing the value of paying taxes. Others feel cheated because they always pay taxes while many in the informal sector do not pay taxes or are under-taxed.

The following view from the field on non-transparency in tax administration is worth quoting in full:

"In fact I am overtaxed. I say so because there are people in the informal sector who gain more but have ways of understating their gains and the IRS has no effective system of checking this. Also, there is too much official opulence and vulgar extravagance. The IRS is not honest; there are persistent rumors that they help people underpay. They are corrupt. VAT is punitive because the poor have to pay the same amount as the rich. I also do not know what the tax money is used for. Tax does not encourage the leadership to be innovative in their thinking because it is an easy way to make money for the government. The corruption in the system is really discouraging; we have no idea how much money is collected and how this money is disbursed. We like to know that we are benefiting from these payments. Because despite all the taxes that are being collected, Ghana is always taking loans from other countries. Most people in the informal sector who own large businesses are helped by the tax collectors to evade tax. Money collected through taxes is not used judiciously and are misused by some people in government".

\section{TAX DELINQUENCY: EVASION, AVOIDANCE AND MORE}

Our research reveals that assumption that the majority of Ghanaians are tax averse is too simplistic. Ghanaians can be very tax loving given a well administered tax system. The theory of tax compliance was pioneered within the framework of game theory. Tax evasion was treated as a risky asset, which is usually determined by tax audit and tax penalties-punishment oriented policies. ${ }^{139}$ However, the game theoretical approach could not completely explain tax compliance. Since then, there have been many studies to explain the behavior of tax compliance in more realistic terms and in a more holistic fashion. These have focused on both economic and non-economic factors as determinants of tax compliance. The concept of tax culture has been used in these later studies to explain the different

Munich Personal RePEc Archive (MPRA) Paper 86415, University Library of Munich, Germany. DOI: https://mpra.ub.unimuenchen.de/86415/1/MPRA_paper 86415.pdf

\footnotetext{
${ }^{138}$ Ghana Revenue Authority \& German Technical Cooperation (2004) Large Taxpayers Union Survey. German Technical Cooperation (GTZ), Accra, Ghana.

139 Sokolovskyi D. (2018) 'Game-theoretic Model of Tax Evasion: Analysis of Agents' Interaction and Optimization of Tax Burden'.
} 
levels of tax compliance and general tax behavior of different countries. ${ }^{140}$

Flowing from the above, much research has in recent years investigated whether values, social norms and attitudes differ across countries and whether these differences have measurable effects on economic behaviour. One area in which such studies are particularly relevant is tax compliance, given both the noted differences across countries in their levels of tax compliance and the marked inability of standard economic models of taxpayer compliance to explain these differences. In the face of these difficulties, many researchers have suggested that the intrinsic motivation for individuals to pay taxes - what is sometimes termed their "tax morale" - differs across countries, and have used experimental methods or information on selected countries to test this hypothesis. ${ }^{141}$

Tax morale can generally be understood as the moral principles or values individuals hold about paying their taxes. Several other approaches have been used to examine this notion. In a common approach, "cultural studies" have often relied upon controlled laboratory experiments conducted in different countries because such experiments can be set up with identical experimental protocols to allow cultural effects to be isolated. Tax morale is likely to be influenced by such factors as perceptions of fairness, trust in the institutions of government, the nature of the fiscal exchange between taxpayers and government, and a range of individual characteristics. Importantly, tax morale is likely to differ across countries because of cultural differences across these countries. There is also a strong negative correlation between the size of the shadow economy and the degree of tax morale in those countries. ${ }^{142}$

Studies done in Switzerland, Belgium and Spain (all countries with a certain cultural variety) have concluded that, generally, the cultural background seems not to have a strong effect on tax morale within a country. However, there is evidence that there is a strong interaction between culture and institutions, which has a strong impact on tax morale. Tax evasion is a sensitive topic and it is difficult to get useful data on it. Researchers have, however, tried to gain insights with experiments. The results indicate that high levels of tax compliance cannot be explained entirely by the level of enforcement. It is important to see the

\footnotetext{
140 Supra 39.
}

141 Riahi-Belkaoui A. (2004) 'Relationship between tax compliance internationally and selected determinants of tax morale'. Journal of International Accounting, Auditing and Taxation 13(2) pp. 135-143, DOI: http:/ / www.sciencedirect.com/science/article/pii/S1061951804000 $\underline{151}$

${ }^{142}$ Alm J. \& Torgler b. (2004) 'Culture Differences and Tax Morale in the United States and in Europe'. Paper presented at the Annual Meeting of the Public Choice Society 2004 in Baltimore and at the 2004 Annual Conference of the National Tax Association in Minneapolis. (On file with author)

143 Torgler B. \& Schneider F. (2004) ‘Does culture influence tax morale? Evidence from different European countries'. Center for Research in process of tax evasion as a staircase with different steps. First, taxpayers have to be seized by a will not to comply. Some researchers have argued that many individuals do not even think of tax evasion, and there are taxpayers who do not even search for ways to cheat at taxes. In fact, experiments indicate that there are individuals who always comply. In a second step, a person with an inclination to dodge his taxes is able to translate his intention into action. Many individuals do not have the opportunity or the knowledge and resources to evade. And in a third step, there are individuals who feel inclined not to comply and check for the opportunity to evade taxes. This is the phase where standard economic theory comes into play, where individuals evaluate the expected value of evasion. The studies point out that differences in compliance behavior across cultures is driven by factors such as differences in tax administration and citizen attitudes toward governments. ${ }^{143}$

There is an interesting view by an anonymous writer using the pseudonym "Otchere Darko": "We [Ghanaians] use tax avoidance, tax evasion and anti-tax demonstrations, or the ballot box [elections] to oppose high taxation by government." ${ }^{144}$ This is not just a passing remark by a disgruntled taxpayer; it is a deep statement which suggests that tax evasion is a function of the citizens' dissatisfaction with the performance of their government. Given this, a country that fails to treat taxation as a part of broader good governance may never be able to raise enough money for the public purse.

More and more large companies are being accused by the GRA of tax delinquency, which leads to the loss of huge sums of money during annual tax mobilization. Between January 2017 and June 2017, the Special Revenue Mobilization Task Force of the GRA said it had recovered evaded tax revenue amounting to about GH $\$ 66.3$ million approximately 15.2 million United States dollars at the exchange rate of the time - in mainly Accra and Kumasi alone. ${ }^{145}$ For the companies which were discovered to be owing taxes but had not yet paid, the GRA Task Force went on to lock up their premises, preventing entry, and threatened to auction off their properties if debts were not paid within 14 days. $^{146}$

Economics, Management and the Arts (CREMA) Working Paper No. 200417.

${ }^{144}$ Darko O. (2011) 'Big Government Must Give Way To Small Government' PeaceFm Online, 21 August 2011. Available at http://www.peacefmonline.com/pages/comment/features/201108 663950.php [Accessed on 28th July 2017]

${ }^{145}$ MyJoyOnline (2017) 'GRA seals off offices of Agams Groups, two others over tax indebtedness'. MyJoyOnline, 22 June 2017. Available at https://www.myjoyonline.com/gra-seals-off-offices-of-agams-

groups-two-others-over-tax-indebtedness/ [Accessed on $28^{\text {th }}$ July 2017]

${ }^{146}$ Finder Newspaper (2017) 'GRA Declares Agambire Wanted' CitiFm, 21 June 2017. http://citifmonline.com/2017/06/21/gra- 
In the LTU survey ${ }^{147}$, some respondents thought that many tax defaulters are not prosecuted. They stressed that arresting and prosecuting tax delinquents in special tax courts and punishing them will have a direct bearing on the perception and attitude of persons towards tax evasion and ultimately reduce the incidence and frequency of the phenomenon. Others thought that taxmen should be more proactive in identifying tax delinquency and should develop a taxpayers' database and software that facilitates the identification of tax delinquency.

During our interviews with the chiefs and the individual taxpayers, they emphasized that traditionally tax defaulters were punished, and because the communities were small it was easy to track defaulters. Some of the punishments they mentioned were very extreme and included banishment and lynching. There was a general sense that tax evasion is a crime and evaders should be punished.

\section{TAX DISPUTE RESOLUTION}

According to respondents, in traditional Ghanaian society, most people do not default in the payment of taxes. When they do, the chiefs and elders settle the matter. According to one chief, this has happened only twice in his living memory; that a citizen had been arraigned before the dispute resolution council for tax delinquency. An overwhelming majority of respondent chiefs said that the institution has the fundamental competence and capacity to resolve tax disputes.

The Courts Act, 1993 (Act 459) stresses the need for civil courts and its officers to "promote reconciliation, encourage and facilitate the settlement of disputes in an amicable manner between and among persons over whom the court has jurisdiction", and counsels them to "promote reconciliation among the parties, and encourage and facilitate the amicable settlement of the suit or proceeding." ${ }^{148}$ Courts with criminal jurisdiction may also "promote reconciliation, encourage and facilitate a settlement in an amicable manner of any offence not amounting to felony and not aggravated in degree, on payment of compensation or on other terms approved by the court before which the case is tried, and may during the pendency of the negotiations for a settlement stay the proceeding for a reasonable time and in the event of a settlement being effected shall dismiss the case and discharge the accused person." ${ }^{149}$

The Civil Procedure Rules ${ }^{150}$ also provides for the settlement of disputes by Alternative Dispute Resolution (ADR). Under the Rules, parties at the pre-trial conference

declares-agambire-wanted-over-gh $\%$ E2 $\% 82 \% B 514 m$-unpaid-taxes/ [Accessed on 28 ${ }^{\text {th }}$ July 2017].

${ }^{147}$ Supra 130

${ }^{148}$ Courts Act, 1993, (Act 459) Section 72.

${ }^{149}$ Courts Act, 1993, (Act 459) Section 73.

${ }^{150}$ High Court (Civil Procedure) Rules 2004, Orders 58, 64 and 68. may - instead of allowing the pre-trial judge to settle the dispute through mediation, negotiation, arbitration or any other mode of settlement - agree to refer their dispute to an external person or body to settle same, and the pre-trial judge shall give directions and time for the settlement.

It is in these areas of dispute resolution that chiefs are willing to assist. Their desire is to engage in general dispute resolution, but they are willing to do a pilot involving only tax cases. Traditionally, chiefs have always had a dispute resolution role; they still do. Several dispute resolution bodies are headed or empanelled by chiefs; they run their own chiefs' courts, traditional councils and judicial committees of the Regional and National Houses of Chiefs that settle disputes. The decisions of the National House of Chiefs in chieftaincy matters are appealable directly to the Supreme Court. ${ }^{151}$ Two ways of engaging chiefs in dispute resolution have been canvassed. Chiefs, with their council of elders, may constitute the courts in their towns and villages. The chiefs and elders are close to the people particularly in the rural areas, and they are well versed in local customs and usages and therefore know customs and traditions applicable to disputes that would be brought to them. Again, membership of the council of elders is not "fixed" such that the absence of a member will delay a hearing because of absence of jurisdiction. More so, where the chief and elders are resident in the area, they may hear and determine cases expeditiously and at limited cost. However, these dispute resolution fora will encounter challenges: there is the issue of absentee chiefs to deal with - chiefs who are not ordinarily resident in their villages and towns; some chiefs' courts are known to charge high fees well above the cost of instituting simple proceedings in the local court; they do not have clear rules of procedure; most procedures are not in writing; there is sometimes no consistency in the application of rules by the chiefs' courts; and some people generally prefer the regular courts because of allegations of corruption in chiefs' courts. ${ }^{152}$

Alternatively, the mandate and jurisdiction of the existing Judicial Committees of the Traditional Councils should be expanded so that they can deal with minor local cases. Many chiefs do not live in their traditional areas; they live and work elsewhere. They would therefore not be available all the time to adjudicate small disputes. The Judicial Committees on the other hand are standing committees of Traditional Councils that have regular meetings at which they deal with matters placed before them. Secondly, the Judicial Committees have mechanisms for adjudication. However, the Judicial Committees meet only at scheduled times and have a specific composition without which it has no jurisdiction. Where they meet only

1511992 Constitution of Ghana, Article 273 (6); Courts Act 1993, (Act 459) Section 4 (4)

152 National Governance Programme (NGP) (2005) 'Traditional Authority and Good Governance: Implications for Democratic Consolidation'. Report of the $7^{\text {th }}$ National Governance Workshop, Organised by the National Governance Programme and the UNDP, Kumasi, $27^{\text {th }}-29^{\text {th }}$ October 2004, p. 25-27. 
in the District Capital, justice will be as far away from the ordinary person as is the case with the regular courts, and delays and great costs will be occasioned. Finally, whatever method is chosen, the institutional and human resource capacities of the chiefs and those who man the dispute resolution mechanisms will have to be built so they function effectively. The neglect to do this for the existing Traditional Councils has meant that they are performing sub-optimally.

In the case of mediation, one tax expert suggests that the country's Finance Minister in collaboration with the GRA should establish some Regulations specifying the categories of tax disputes that may be resolved by Mediation and those that may not. ${ }^{153}$ This is because the Alternative Dispute Resolution Act ${ }^{154}$ lists disputes that are not capable of resolution by mediation or arbitration. The list includes disputes apropos of national or public interest, the environment, the enforcement and interpretation of the Constitution and any other matter that by law cannot be settled by ADR. ${ }^{155}$ Tax disputes are not included in this list, but they could be subsumed under disputes relating to national or public interest. The clause is an unfortunate blanket bar against the resolution of many tax disputes by ADR, a process which could potentially save the government lots of money and an unimaginable amount of time. It is, therefore, important to clarify whether, and if so, which tax disputes may be settled by ADR.

Whatever the constraints, there are several reasons why the idea of involving chiefs in dispute resolution has serious advantages and should not be dismissed lightly. The closeness of the dispute resolution venue to citizens, the use of the local language in which parties and adjudicators are at ease and are well versed, the absence of technical jargon in the proceedings, and a simple and understandable procedure are just a few advantages.

Of course, as with anything that shows great signs of benefit, we must be mindful of the risks associated with chieftaincy systems in Ghana. An international conference on chieftaincy held in 2003 drew the following conclusion:

"In view of the lack of accessibility for the majority of
Ghanaians to the regular courts of Ghana, the chief's
tribunal must be re-introduced and made part of the
judicial system of Ghana. Chiefs must be introduced
to new techniques in adjudication; to the fine
principles of the rule of law and the equality of
everybody before the law, with some education in
judicial process so that they are willing to clean their

${ }^{153}$ Kasser-Tee C. B. (2016) 'Tax Assessment, Tax Disputes and Mediation: Making it easier for the Taxpayer and the Commissioner General of the Ghana Revenue Authority'. Modern Ghana. 7 August 2016. (First serialised in the Business \& Financial Times in Ghana). Available at https://www.modernghana.com/news/709807/taxassessment-tax-disputes-and-mediation-making-it-easier.html [Accessed on 9th December 2020]

${ }^{154}$ Alternative Dispute Resolution Act, 2010 (Act 798)

${ }^{155}$ Section 1 of the Alternative Dispute Resolution Act, 2010. (Act 798)
stables...[Nonetheless], Chiefs in Ghana have not always conducted themselves well. They have not administered justice impartially and they have not always accounted faithfully to their states with regards to the management of resources... ${ }^{156}$

In addition to the caution given above, we should note that given the willingness of chiefs to assist in some aspects of tax mobilization and administration, conflicts of interest may arise where the chiefs also engage in dispute resolution relating to taxes collected and administered with their active assistance.

\section{TAXPAYER SATISFACTION}

Taxpayer satisfaction is directly linked to tax morality, tax compliance and tax revenue levels. Ghanaians would love to pay taxes if only the tax system were better in several respects. "If tax is for a good purpose, I would not mind paying $50 \%$ of my income", says one respondent. With the current tax system, Ghanaians literally hate the taxman and hate paying taxes. "I actually feel pains in my body when I pay tax", says another respondent. There was open hostility from some people who assumed our field staff were from the IRS. Some of our staff got scolded several times. Many respondents complained about the tax collectors and named corruption as one of the reasons why they would not want to pay tax. They also noted that there are too many taxes and it is quite confusing as to what to pay, what is being paid and at what point in time it should be paid.

Some of the respondents were satisfied with the tax system. They indicated as a reason for their satisfaction the fact that the tax collectors often come directly to the shop and collect the money there, so that they are not obligated to queue at the tax office. Tax collectors also sometimes agree to payment in instalments. The few who were comfortable with the tax system were unhappy that they did not have the opportunity to negotiate (literally bargain over) the amount of tax that is payable. Negotiation, bargaining and discussion are a huge component of Ghanaian culture. In our interviews, respondents preferred the tax officials of the District Assemblies to the IRS because it is possible to say to the former: "I have not sold enough goods today, go and come tomorrow for your tax". A tax system that is anti-negotiation, anti-bargaining and anti-discussion cannot sit well with the Ghanaian.

So many reasons were given for popular dissatisfaction with the tax system: taxpayers do not know what tax monies are used for; government officials who live off tax

${ }^{156}$ Baku, K. (2003) 'Chieftaincy in Africa: Culture, Governance and Development'. Paper presented at the Summary of International Conference Proceedings at the International Conference Centre. Accra Ghana, January 6-10 2003; Adeyiga G. K. (2013) 'Baseline Study of Ghana's Tax System'. Commissioned by Ghana Integrity Initiative (GII) in collaboration with OXFAM America with funding from German International Development (GIZ). September 2013, Accra. DOI: $\quad$ http://maketaxfair.net/assets/Ghana-Baseline-study- 
revenues are corrupt and wasteful; the tax burden is too high; "Tax rates are too high, even bonuses and overtime are taxed"; income levels are too low; the rich should pay more taxes than the poor; there is no encouragement or incentive for regularly paying taxes; taxpayers do not see the direct benefits of paying tax; there is little information and education about the tax system; taxpayers do not appreciate the importance of taxation; there is near total ignorance about tax rebates, deductions and exemptions that the taxpayer is supposed to enjoy; many in the informal sector are tax delinquent, sometimes with the connivance of tax men and this discourages others from paying taxes; there is little transparency in the way tax is imposed and collected; there is no way of telling whether or not tax revenues are used judiciously; if Ghana is still borrowing heavily externally, then tax revenues are not helping out; some modes of tax collection are crude and unfriendly; taxes are too many and varied and should be consolidated; sanctions for tax evasion are too minimal and enforcement is lax; "I think it is a way of robbing Ghanaians...after taking the money we do not hear anything anymore".

In April 2004, the Large Taxpayers Unit (LTU) survey was conducted. The results indicated that $75 \%$ of the large taxpayers are more satisfied with LTU than with the other three individual revenue agencies (IRS, VATS and CEPS). Also, $72 \%$ of the respondents welcomed the implementation of a one-stop tax agency. The large taxpayers also pointed out some areas for improvement for the LTU. Some $66 \%$ want to be provided with more specific information, whilst $79 \%$ like to get information via the internet. Finally, $60 \%$ would like to see further improvements in the expertise of LTU employees. Other areas needing improvement according to the survey are provision of more and better information and guidelines for the taxpayers on exemptions, refunds, obtaining tax clearance certificates and similar processes; taxpayer education; speedy and efficient tax services; reducing corruption; proper record keeping of taxpayer records; better customer service; training for schedule officers of taxpayers; computerization of receipts; a reduction in paperwork and a move towards electronic processing; better attention to taxpayer problems; information on rules and regulations (including regularly updated manuals that include notes on how tax laws are applied); clarifications on contradictory aspects of tax laws; simple and userfriendly tax forms; use of incentives to encourage tax compliance, not just punitive measures; improvement in the currently confrontational relationship between tax agencies and taxpayers.

\footnotetext{
157 Daily Graphic (2005) 'AGI Celebrates Fifth National Industrial Week'. Daily Graphic, 22 November, 2005.

${ }^{158}$ See http://www.gra.gov.gh/index.php/about-us [Accessed 10th December 2020]

${ }^{159}$ Ghana Revenue Authority (2019) 3rd Strategic Plan: 2019-2021. Ghana Revenue Authority, Accra, Ghana. DOI:
}

The way in which tax is imposed, collected and used mirrors the governance of a State. Ghanaians currently do not love to pay taxes for a multiplex of reasons. Tax authorities cannot change this by wishing it away. But they have control over a number of factors such as customer service, that enormously impact on the willingness of taxpayers to meet their obligations. Before I move to the final section of this article where I make specific recommendations for improving Ghana's tax culture, I address, immediately below, the crucial roles of the revenue agencies and traditional authority in creatively addressing this most crucial governance issue.

\section{THE ROLES OF REVENUE AGENCIES}

A forum held in Accra by the Association of Ghana Industries and the revenue agencies as part of the fifth National Industrial Week had as its theme: "Making Ghanaian industries price-competitive: The role of revenue agencies" ${ }^{157}$ Revenue agencies, as the key institution in tax administration, can make or unmake an economy. Most of the comments and suggestions made immediately above on taxpayer satisfaction are directly related to revenue agencies. The GRA is already showing the way. It gave its core goals for the period 2015-2017 as optimum revenue collection in a cost-effective manner, responsive customer service, compliance with statutory non-revenue obligations, a transparent tax environment to enhance voluntary compliance and a professional and credible organization. ${ }^{158}$ According to its Third Strategic Plan for 2019-2021, the GRA's strategic goals are to grow revenue, improve customs and domestic tax compliance, leverage information communication technology, enhance administrative efficiency, and develop professional and motivated staff. ${ }^{159}$ It appears that what the taxpayers want is what the GRA wants to give.

\section{TAX AND TRADITIONAL AUTHORITY}

The significance of traditional governance in Ghana has been such that the various constitutions of the country have guaranteed its existence and operation. ${ }^{160}$ The 1992 Constitution of the Republic of Ghana continues to recognize and guarantee the institution, although it bans chiefs from participating in partisan politics. The Chieftaincy Act, 2008 (Act 759) sets out the guidelines for the functioning of the various Chieftaincy institutions. It legitimizes and defines the operation of the various Houses of Chiefs and mandates the National House of Chiefs to undertake the progressive study, interpretation and codification of customary laws. The constitutional guarantees reflect the relevance of traditional governance in modern democratic governance and justify clearly the

https://gra.gov.gh/wp-content/uploads/2019/11/GRA-13FINAl.pdf

${ }^{160}$ Kumado C. E. K. (1990-92) 'Chieftaincy and The Law In Modern Ghana'. University of Ghana Law Journal 18(1), pp 194-216. At p. 214 
inclusion of the institution in any discourse on nation building and development ${ }^{161}$.

That the inability of central government to follow through on its policies and development agenda in the remotest parts of the country has created leadership and authority vacuums is indisputable. This vacuum is filled by traditional authority. Again, the traditional authorities, as custodians of the land and some other natural resources, play a critical role in the economic activities of the people, such as farming, mining, and construction. As custodians of the history and culture of the people, they are also regarded as one of the critical echelons of leadership through which the Ghanaian development agenda of poverty reduction and wealth creation could be achieved. ${ }^{162}$

Research on "chieftaincy, governance and development" has revealed that a significant number of Ghanaians are in favor of maintaining the institutions of traditional leadership - albeit with government support - to develop the capacity of the institutions to function effectively. Furthermore, in a communiqué issued in January 2003 during an international conference on Chieftaincy in Africa, traditional leaders called for a review of their role and their incorporation into mainstream governance. "The chiefs demanded that:

- The chieftaincy institution be assisted to enhance its profile as an integral and viable component of the contemporary socio-political structure of Ghana.

- The chieftaincy institution be adequately resourced from the consolidated fund.

- The capacity building efforts of the chieftaincy institution be supported financially.

- The institution be seen as a critical and indispensable partner in governance at the local level... and that the Constitution be amended to allow for the institutional participation of chiefs at these levels of governance.

- The judicial function of chiefs be recognized, properly defined and enhanced..."163

It is clear that traditional authorities are willing and waiting to participate in several aspects of governance in Ghana, including the governance of the tax administration system. This view was buttressed by the receptiveness of the National House of Chiefs (following our presentation of the preliminary findings of the research process to them) to listen to us, brainstorm with and point us to avenues for collaboration with the chieftaincy institution in tax governance.

\footnotetext{
1611992 Constitution of Ghana, Chapter 22

162 Supra 144.p. 1

${ }^{163}$ Supra 144. p. $1-2$.

${ }^{164}$ Supra 144. p. 2
}

In the last two decades, a debate has gone on about the appropriate roles to be played by traditional leadership in the management of local and national resources, the mobilization and involvement of communities as partners and stakeholders in development, the search for strategies for containment and resolution of conflict and creation of harmony and peace. Of great significance is the fact that the academic backgrounds and profiles of chiefs in the modern era have improved considerably. Most chiefs are now educated. Some of them are well-trained professionals. A regrettable trend in this encouraging development is the emergence of the phenomenon of the "absentee chief". ${ }^{164}$ This poses a challenge to traditional governance and the role of chiefs in development efforts in their communities since they may never be available in those communities for direct assistance in those efforts.

On the other hand, "there are dissenting voices which point to the anachronistic nature of the institutions of traditional leadership." ${ }^{165}$ Central government has taken over the military, judicial, administrative, legislative functions and economic resources of chiefs, and the institution of traditional leadership is bedevilled with conflict and disputes in connection with land and succession. ${ }^{166}$ Chiefs have not always conducted themselves well. They have not administered justice impartially and they have not always accounted faithfully to their states with regards to the management of resources. ${ }^{167}$ Others are downright dismissive of the institution and draw attention to the lowering levels of allegiance for chiefs by the citizenry.

Even though many argue today that chieftaincy is incompatible with the demands of the modern state, there is evidence that chiefs champion modern causes. The lessons are clear. Chiefs have been and can be agents of development. Despite the above-named problems with the chieftaincy institution, the potential of chieftaincy for effective leadership is not in doubt, even if they seem to operate in parallel, and in some cases, in contradiction to the governance agenda of central government. The reason is that the Ghanaian society is still predominantly traditional in spite of the on-going transition to modernity. Given that only a mere $30 \%$ of the population is modernized, the remaining $70 \%$, which is predominantly traditional, still looks upon chiefs as performing important religious and civil functions. Furthermore, central government has relied on chiefs as important links between them and people in the rural areas and have utilized their offices in reaching out to the rural communities. Central government also uses chiefs to staff statutory Boards, to mediate in areas of conflict and

\footnotetext{
165 National Development Planning Commission (NDPC) (2003) Ghana Poverty Reduction Strategy (GPRS) (2003-2005): An Agenda for Growth and Prosperity. Accra, Ghana. February 19, 2003. p. 127 166 Supra 144. p. 2

167 Supra 148. p.35.
} 
disputes on behalf of Government, and generally as cultural ambassadors for Ghana. ${ }^{168}$

The general feeling, however, is that the rather residual functions given to traditional leadership do not afford chiefs the opportunity to play an effective role in modern governance. There is a need, therefore, to redefine the roles that a traditional leader can play in order to make him or her an integral part of the modern governance paradigm. "Chiefs must consider the time opportune for them to review traditional governance from within; to critique themselves and rid the institution of certain excesses and aberrations; to repair the damages done to the image of the institution; and to build its capacity towards integration into mainstream modern governance" ${ }^{169}$

Research has revealed that with capacity building and training, chiefs could play important roles in resource management through data collection and documentation of information on resources in their traditional areas. It is therefore important to review the role of chiefs in the economic lives of their people in general. As previously noted, contemporary governments rely on chiefs as important links between them and the people in rural areas: governments have utilized the offices of chiefs to explain important government policies to the people. On the balance, it has been argued that there is a need for the redefinition of the roles that a chief can play to make him an integral part of the modern development process. ${ }^{170}$

There is a constitutional injunction against anyone taxing citizens except government. Yet, the evidence is that chiefs mobilize significant amounts of revenue and other resources from their citizens. ${ }^{171}$ These are meant to be "voluntary" contributions from stool and skin subjects for various purposes including the execution of development projects decided upon by the chiefs and elders, sometimes with input from the citizens. The evidence is that these contributions are not entirely voluntary. When, for example, a Chief takes money called homage or levies as a pre-requisite for the passage of a corpse through his jurisdiction, the payment can hardly be said to be voluntary. There is also evidence that some chiefs, following the diminishing of their powers of taxation, use other undesirable methods of getting money. These

\footnotetext{
168 Supra 144. p. 1-5

169 Supra 144. p. 2-3.

170 Supra 148. p. 51 and 89.
}

${ }^{171}$ During our interviews, a significant number of chiefs objected to the use of the term "subjects" to describe their constituents. They preferred the term "citizens". In their opinion, the latter term was more dignifying and consistent with the range of rights (and resulting obligations on the chiefs), which their constituents have.

${ }^{172}$ See, for example, the State Lands Act, 1962 (Act 125) and the Administration of Lands Act, 1962 (Act 123).

${ }^{173}$ Ross W. (2007) 'Ghana King Burial Draws Thousands'. BBC News, 27 January $2007 . \quad$ Available at http://news.bbc.co.uk/2/hi/africa/6306433.stm [Accessed 14th include dipping into stool land revenue and forestry royalties, multiple sales of the same piece of land to several buyers, and the charging of inordinate fees for the performance of traditional functions of the chief such as dispute resolution. In light of the above, the majority of taxpayer respondents were very opposed to the participation of the chieftaincy institution in tax matters. What then can the role of chiefs in improving the tax culture of Ghanaians be? Chiefs are still a very powerful constituency in Ghana. The last serious attempt to strip chiefs of their status and power were those undertaken by Dr. Kwame Nkrumah when he sought to control stool lands, one of the most important bastions of chiefs' status and powers. ${ }^{172}$ There are Traditional Councils in all traditional areas, Regional Houses of Chiefs in the administrative regions of Ghana (even as attempts are being made to establish Houses of Chiefs in the six newly created Regions) and a National House of Chiefs in Kumasi. There is also a National Chieftaincy Secretariat in Accra and a Ministry for Chieftaincy. The chieftaincy institution is well represented in the Council of State and other national bodies such as important committees and commissions of inquiry. The National Reconciliation Commission and the Constitution Review Commission are just two of the more important Commissions of Inquiry that had significant representation of Chiefs. The Constitution of Ghana contains a whole chapter on the Chieftaincy Institution. Chiefs in Ghana today still hold court and settle many disputes between their citizens. There is evidence that some of the disputes that they resolve are well beyond their jurisdiction. Some chiefs settle criminal matters involving felonies that should be referred to the police under our criminal laws. Parties to such disputes, who submit to the unlawful jurisdiction of the chiefs, accept the ruling they give and abide by them with more gusto and acceptance than they would a regular court of law.

In important matters such as land reform, the views, endorsement and implementation support of chiefs are strategically courted. Anyone who is in some doubt about the centrality of the chieftaincy institution needs only remember the quality, quantity and range of persons and institutions who paid their respects to the late Ga Mantse ${ }^{173}$ and the late Asantehene, Opoku Ware $\mathrm{II}^{174}$, the powerful

December 2020]; Takyi-Boadu C. \& Norley N. (2007) ‘Ghana: Boni Nii Amugi II Laid to Rest'. All Africa. 29 January 2007. Available at http://allafrica.com/stories/200701291331.html [Accessed on 14th December 2020]; Modern Ghana (2007) 'Thousands throng Nii Amugi's funeral'. Modern Ghana, 27 January 2007. Available at https://www.modernghana.com/news/122707/thousands-throngnii-amugis-funeral.html [Accessed on 12th December 2020]

${ }^{174}$ Kaufman M. T. (1999) 'Opoku Ware II, King of Asante, Is Dead at 89'. New York Times, 4 March, 1999. Available at http:/ / www.nytimes.com/1999/03/04/world/opoku-ware-ii-kingof-asante-is-dead-at-89.html [Accessed on 12th December 2020]; Walker J. (1999) 'Obituary: King Opoku Ware II of Ashanti'. Independent, 5 March 1999. Available at http://www.independent.co.uk/arts-entertainment/obituary-king- 
force of initiatives and pronouncements by the Asantehene and the Okyehene, and the delicate issues surrounding the death of the Ya Na, Yakubu Andani. ${ }^{175}$ The Chieftaincy Institution controls about $80 \%$ of lands in Ghana. ${ }^{176}$ Matters of national importance are discussed at the meetings of the General Assembly of Chiefs and of the various Houses of Chiefs: decisions are taken on these matters, the position of the chieftaincy institution on the matters is stressed, feedback is given to relevant stakeholders and above all, these stakeholders take them seriously. ${ }^{177}$ All these are evidences of the resoluteness of the chieftaincy institution, the great public regard for the institution in Ghana and its potential for advancing or retrogressing any national endeavor, including the building of an excellent tax culture in Ghana. Although a few respondents cautioned that chiefs should not be involved at all in taxation because they are corrupt and because of lowering levels of allegiance to chiefs by the citizenry, it is very safe to conclude that improving the tax culture of Ghanaians will fail unless the chiefs are involved in the exercise.

Nearly half of the respondents do not think chiefs and traditional leaders should be involved at some level in the tax system of Ghana. The other half thinks they should. The various comments we collated from respondents individual taxpayers and chiefs alike - with regard to this question was that the import of the question was taken to be whether or not chiefs should collect taxes. Almost all respondents agreed that chiefs should not be involved in any way in the direct collection of taxes. In their opinion, this is incompatible with the dignity of the institution and will cause citizens to lose respect for their chiefs. Chiefs should be promoters and canvassers of taxation and not tax collectors and enforcers.

Respondents, however, saw very critical roles for the chieftaincy institution in other aspects of the tax system. These included assisting taxmen to mobilize taxes by helping mobilize their citizens for tax collection, sending information out about tax obligations, educating their citizenry on the need to pay taxes and encouraging them to do $\mathrm{so}^{178}$, assisting in the resolution of disputes arising out of the mobilization of taxes, and in limited circumstances,

opoku-ware-ii-of-ashanti-1078403.html [Accessed on 14th December 2020]

${ }^{175}$ Allotey G. A. (2019) 'Yaa-Na Yakubu Andani funeral rites ongoing amidst tight security'. Citi Newsroom, 13 January 2019. Available at https://citinewsroom.com/2019/01/yaa-na-yakubu-andani-

funeral-rites-ongoing-amidst-tight-security/ [Accessed on $14^{\text {th }}$ December 2020]; Abdul-Majeed Y. (2019) 'Ghana: Yaa-Naa Andani's Funeral Underway ... in Yendi As Peace Returns to Dagbon'. All Africa, 14 January 2019. Available at https://allafrica.com/stories/201901140325.html [Accessed on 14th December 2020].

${ }^{176}$ Ministry of Lands and Forestry, (1999) National Land Policy. Government of Ghana-Ministry of Lands and Forestry, Accra, June 1999.

${ }^{177}$ Kenu D. (2019) 'House of Chiefs urges Government to enhance Corruption Fight'. Graphic Online, 27 September 2019. Available at https://www.graphic.com.gh/news/general-news/house-of-chiefsurges-govt-to-enhance-corruption-fight.html [Accessed on 14th collating taxes from households and holding it for collection by tax authorities.

It was only in the Northern Region that a good number of respondents, including chiefs, thought that chiefs could be involved in direct tax collection. In their opinion, there was practically no difference between tax collection and the mobilization of other forms of revenue by chiefs from their citizens. Such a suggestion emanating from the northern part of Ghana is not very surprising since that area was not much of a revenue base for the colonial government and so the full and direct brunt of the colonial tax policies and their operationalization were not really felt in these parts.

There was abundant evidence that chiefs already play these roles in the tax administration system, albeit informally and on an ad hoc basis. One respondent cited an example of Lawra in the Upper West Region where the District Assembly involved the chief in mobilizing revenue and collected for the period far more revenue than it had ever been able to collect. Most of the chiefs have welfare and other levies set up in their traditional areas and they have effective means of collection and punishment of defaulters. For example, defaulters are not given any financial aid in times of misfortune until tax arrears are paid. In the northern region, our field researchers were shown bags of millet representing resources mobilized from the citizens by the chief.

There were strong calls from the chiefs themselves for institutionalizing these roles and making them more effective and efficient at performing them. During a brief presentation of the highlights of the research project to a meeting of the National House of Chiefs in Kumasi ${ }^{179}$, the reception and response by Nananom $^{180}$ was very critical but warm and useful. The National House of Chiefs, speaking through its President and Principal Members, undertook to convene a high-powered committee of chiefs to study the draft report and give feedback. The House first noted the constitutional injunction against anyone, except the government, imposing tax and underlined the fact that they were not interested in assuming any responsibility for the actual collection of taxes. The House also indicated its

December 2020]; 3 News (2020) 'Go to court instead of inciting public - National House of Chiefs President to NDC'. Ghana Web, 11 December 2020. Available at https://www.ghanaweb.com/GhanaHomePage/NewsArchive/Goto-court-instead-of-inciting-public-National-House-of-ChiefsPresident-to-NDC-1131092 [Accessed on 14th December 2020]

${ }^{178}$ Of the 29 chiefs interviewed, 28 responded that they actively encourage their citizen to pay taxes.

${ }^{179}$ Atuguba R. A. (2006) 'The Tax Culture of Ghana: Presentation of Research Findings to Select Chiefs'. A Paper Presented to Members of the National House of Chiefs at a Seminar organised by the German Technical Cooperation and the Legal Resources Centre, Accra, Ghana, 21st July, 2006.

${ }^{180}$ This is a term used to address chiefs or refer to chiefs in most of the Southern parts of Ghana. It is sometimes applied to all Chiefs in Ghana although most major ethnic groups have a corresponding term. 
willingness to partner with government in its bid to improve the tax culture of Ghanaians by assisting in all aspects of improving the tax system, except the actual collection of taxes on behalf of government. These could include disseminating information on tax matters, encouraging their citizens to pay taxes, supporting tax mobilization and protecting the rights of their citizens in tax administration. They also indicated that their traditional role of dispute resolution could be expanded to explicitly include the resolution of aspects of tax disputes. Their popular mobilization role could also be used in aid of mobilizing their citizens for tax education and tax collection.

Generally, respondents thought that the role of traditional rulers should be limited to tax information, tax education, aspects of tax mobilization and tax dispute resolution.

\section{RECOMMENDATIONS FOR IMPROVING GHANA's TAX Culture}

It is critical that steps are taken to improve the tax culture of Ghanaians. This can be done by working to transform the tax system in Ghana so that it is more equitable and better governed. It is hoped that the recommendations outlined below will generally lead to an improvement in the tax culture of Ghanaians.

This section of the article is very short. This is deliberate. The idea is to propose very effective, low-cost measures for improving Ghana's tax culture. This will include ideas for broadening the tax net and for better tax administration; measures for better customer satisfaction, for ensuring voluntary tax compliance, for better governance of the tax system; better systems of protecting the rights of taxpayers; and better processes for dispute resolution.

The measures proposed are to ensure that improving the tax culture of Ghana is cost-effective. It is true that the broader dividends to governance and democracy that will inure with an improved tax culture are incalculably beneficial. In the face of resource constraints, we need to limit the interventions we seek to make to those which are practically beneficial and not gigantically costly. Also, the leanness of the recommendations affords the chance for the stakeholders identified here to flesh them out in ways that they alone can.

\section{TAX MOBILISATION}

There is the need to increase the number and competence of personnel employed to collect taxes. This is especially so for the huge informal sector that is a part of Ghana's tax paying public. The colonial government was successful in the crude collection of taxes mainly because they used

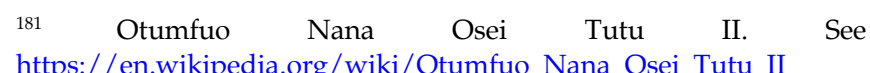

chiefs and teachers who could be found at every part of the country. This suggestion will automatically widen the tax net. Today, state agencies use teachers and other professionals who are very geographically spread in the country for national mobilization efforts related to the registration of voters, voting and the national census. The current Asantehene ${ }^{181}$ has also used students during holidays to assist the Municipal Assembly in Kumasi to collect annual land rates.

Those who assist in tax mobilization should be well remunerated according to a scheme that motivates them to collect more and more taxes. In the system of revenue generation used by the chiefs of old in the Asante kingdom, the ahenkwas ${ }^{182}$ who executed the revenue generation mandate of the chief were appropriately remunerated. In the Asantehene's exercise mentioned above, the agreement was that the more a student collected in taxes, the higher the percentage of the commission paid to her.

From our interviews, there is a strong dislike for the taxman. Owing to the colonial policy of making chiefs the collectors of taxes, the appointment of chiefs - without due regard for tradition - specifically for the collection of taxes and related matters, and the endorsement of crude and undemocratic processes of tax collection, the taxman and taxation have come to carry a certain public disapproval and loath. Some methods of tax collection and enforcement currently being used by the revenue agencies and the District Assemblies are reminiscent of the colonial tax collection processes and this has not helped matters. It is therefore important, for the purpose of improving tax mobilization, to improve the status of the taxman. This should be done both at the macro and the micro level. Some have suggested that the Chief Taxman should have a position equivalent to that of a minister of state. There are other ways of doing this. In the past, various governments have elevated the status of offices or thematics (such as "governance") by associating them with the office of the President. At the micro level, the use of respectable professionals in aid of tax collection, at least some of the time, and other such measures will greatly improve the status of the taxman. In this regard, it is not completely objectionable to have chiefs do actual symbolic tax collection some of the time in order to improve the status of the taxman at the local level. This way, the respect that most Ghanaians still have for their chiefs will rub off on the tax men and hopefully remain. Further, this will be a practical exercise through which chiefs will have a fair sense of tax mobilization issues to better act as mediators in tax disputes and to better protect the rights of their citizens vis-à-vis the tax administration.

If any of these suggestions are agreed upon for implementation, there will be the need to institute mechanisms for ensuring that the process is well managed

${ }^{182}$ A Twi term which means "Servants of the Stool". 
to avoid all the issues of corruption and sub-optimality that are the bane of the current processes of tax mobilization. In the case of raising the status of the chief taxman, care must be taken not to over politicize the position, especially as Ghanaians currently think that tax revenues are mostly used to enrich government officials. In the case of the recommendation on using chiefs some of the time for tax collection, potential issues of conflict of interest (related to other proposed roles in tax dispute settlement and protecting the tax rights of their citizens) will have to be ironed out as a condition precedent.

\section{TAX INFORMATION AND TAX EDUCATION}

There is overwhelming evidence that tax information and tax education are lacking even to the fairly sophisticated. This can be improved through publicity and tax education. Many consultancy and NGO recommendations focus heavily on education. These are, however, usually not targeted and customized enough. The idea is to get a precise sense of the particular information and educational needs of the various types of taxpayers (large taxpayer, individual formal sector taxpayer, individual informal sector taxpayer, and so on) and direct information and education to address the particular needs that are assessed in a manner and via media that will fully address the actual needs as determined. The determination of these needs and the mechanisms for addressing them are crucial to any tax education effort. An intelligent observer we interviewed had this to say:

"Modern taxation is a foreign concept so you need to familiarize the average taxpayer with the reasons for carrying out taxation. When I talk of publicity, I do not mean adverts on the radio and television. Neither do I mean seminars. These are governmental concepts that don't work. People attend them for the sake of collecting the per diems that will be given. Thereafter, they do nothing with the information gained. This kind of publicity has to involve the chief and Odikro ${ }^{183}$ to be effective. During Akwasidae ${ }^{184}$ and other such festivals for instance, Nananom will be willing to publicize the notion of taxation. But with all this must come a sufficient allowance to carry out all these tasks".

It is clear that any effort at tax information and education must address the historical nature of taxation, the transition to a modern tax system, the interface of the traditional and the modern systems, and ways in which they may contradict, obstruct and complement each other. In the light of the traumatic experiences of taxation that were experienced during colonial rule, and some of the rough experiences some taxpayers complain of today, it is critical that any effort at tax information and tax education carry an image of the taxman

183 This is a Twi term which means "headman".

${ }^{184}$ A festival in honour of the Ashanti Chief and ancestors, it also commemorates the date the Ashanti Golden stool was magically brought down from heaven. and of tax enforcement that is as distant as possible from the colonial and neo-colonial experience.

A global source book, "Building Tax Culture, Compliance and Citizenship", gives various innovative projects and ideas originating from local governments of various developing Latin American and African countries on how to sensitize and educate citizens on taxation. Examples are a Citizen Culture Festival in Guatemala, a Schools Outreach Program (which believes it is never too early to start educating on taxation) in Kenya, and even a Soap Opera on taxation in Nigeria. In the words of the book, "Taxpayer education is the bridge linking tax administration and citizen" ${ }^{185}$ It is key to use methods that are more relatable to the people if we aim for maximum participation and understanding. Simply organizing seminars on taxation will not solve the problem.

Finally, there is an issue as to who to focus on in terms of tax information and tax education. From a results-oriented, quantum of tax analysis point of view, it makes sense to focus on the big fishes. From a tax culture point of view and from the point of view of widening the tax net, this may not be true and it may make sense to focus on the average, ordinary taxpayer.

\section{TAXPAYER SATISFACTION}

As noted earlier, the way in which tax is imposed, collected and used by the state mirrors the governance of a State. Above all, the taxpayers' perception of how tax is generated and used directly impacts tax morality, tax compliance and tax revenue levels. Taxpayer satisfaction is therefore a crucial factor for the public perception of tax administration. It is therefore important to make recommendations for improving taxpayer satisfaction.

The section on taxpayer satisfaction in this article contains a long list of matters to be addressed in order to ensure taxpayer satisfaction. Some of the suggestions are even contradictory. It is important to interrogate those suggestions further, streamline the suggestions, identify linkages between various suggestions, and then prioritize them for implementation.

Higher voluntary compliance means higher revenue and lower collection costs. Even if citizens do not like to pay taxes, tax authorities can use their control over the instrument of customer service to begin to change this. Customer service has proven to have an enormous impact on the willingness of taxpayers to meet their obligations. Our interviews showed that many people hate to queue to pay taxes and are happy when the tax man comes around to collect them. The tall list of concerns in the customer satisfaction section of this article are mostly related to customer service. The only way to offer first-quality service is to find out the wishes and the needs of

185 Supra 47. 
your customers. It is therefore important to institute regular tax surveys to generate this information.

Government can also employ technological tools which will provide the opportunity for taxpayers to fulfil their obligations without being physically present in a tax office. A simple Taxpayers Mobile App which has integrated mobile payment options would enable a taxpayer to fulfil his or her tax obligations without closing shop to visit a tax office.

\section{TAX LEGISLATION}

Ghana's tax culture is peculiar to Ghana. This means that, to have effect, Ghana's tax laws must be peculiar to Ghana to some extent. A few examples of Ghana's tax peculiarity are worth mentioning here. Tax men are less visible in the rural areas: one respondent says he moved from Kumasi to set up shop in Tamale in order to avoid the myriad of tax authorities in the former town. Additionally, tax men are seen as oppressive; reminiscent of courts and bailiffs barricading businesses and prisons. In an economy where people live from hand to mouth and where there is a low savings rate, ${ }^{186}$ it is difficult to require people to save up their taxes and pay up at the end of the month, unless it is deducted at source. It was for this reason that commercial transport operators in Ghana arranged to pay taxes quarterly and not annually. ${ }^{187}$ Again, Ghanaians store up wealth or save in things other than money such as real estate. All these peculiarities of Ghana's tax culture require that legislative measures be put in place to ensure a tax system that is culturally friendly and more capable of generating voluntary tax compliance.

Culturally-friendly rules do not have to occasion a legislative change at the Parliamentary level. These could be done as rules and regulations or as administrative instructions issuing from the Ministry of Finance or the revenue agencies. Some respondents asked for simple, illustrative manuals to guide them in meeting their tax obligations. Such manuals could be configured to take account of all the factors that make Ghana's tax culture unique. This way, voluntary tax compliance and ultimately revenue levels could be improved.

\section{TAX TRANSPARENCY}

Next to tax information and tax education is tax transparency. Here the key concerns relate to ensuring information flow from tax administrators to taxpayers and achieving accountability for tax revenues collected. Taxpayers will want to be informed about tax reliefs of various kinds which they know exist but of which they have no details. They will want that rules, processes and forms for tax reliefs are readily available. Taxpayers will also need to have clear and practical

\footnotetext{
${ }^{186}$ The highest ever real GDP growth in Ghana was expected to be recorded in 2017 at 13.2\% (according to the Ghana Shared Growth And Development Agenda (GSGDA) II, 2014-2017 Volume I: Policy Framework Government Of Ghana National Development Planning Commission (NDPC) December 2004). Yet the GDP growth recorded at the end of the year was 7.9\% (according to The Budget Statement and Economic Policy of the Government of Ghana for the 2018
}

guides for how taxes are assessed. Taxpayers will finally need simple statements on what monies paid as taxes are being applied to. Regular publications on what proceeds of taxation are used for, without taxpayers demanding for these, will be most appropriate.

\section{TAX DISPUTE RESOLUTION}

Using the regular courts for tax dispute resolution does not seem to be very popular with Ghanaians. As noted earlier, very few tax cases are resolved in the regular courts; and this is in the face of a commercial court with enhanced court processes and oversight that lists tax cases as part of a broader list of cases that may be tried in that court. This means that the bulk of tax disputes are resolved at the administrative level only. In any case, the cost of litigation, relative to the quantum of tax charged for most ordinary taxpayers, means that it is economically wiser to accept slightly higher assessments and fight these at the administrative level than to take the matter to court.

In light of this, it is proposed to strengthen the dispute resolution mechanisms with the revenue agencies to make them easily accessible, fast and effective at resolving tax disputes. It is also proposed to enhance the dispute resolution roles of the chiefs to cover local tax disputes. It is also possible to maintain a roster of chiefs who may act as mediators in tax disputes at the pre-trial stage in those tax disputes that make their way to the court. We should note, however, that given the willingness of chiefs to assist in some aspects of tax mobilization and administration, conflicts of interest may arise where the chiefs also engage in dispute resolution relating to taxes collected and administered with their active assistance.

For the rules of the ADR Act to be applicable and regulate dispute resolution processes in tax matters, same must be statutorily removed from the preventive scope of the Act, which excludes matters of public or national interest and into which category tax disputes may fall.

\section{THE ROLE OF TRADITIONAL AUTHORITY IN TAXATION}

The aim of the recommendations in this section is meant to see how good practices in the traditional modes of resource mobilization could be brought to bear on taxation and tax administration in Ghana. It is fairly possible to cast formal taxes in the light of traditional revenue mobilization philosophies, processes and tactics. How can traditional authorities working within the current legal framework for tax administration assist in the mobilization of tax

Financial Year presented to Parliament on $15^{\text {th }}$ November, 2017 by the Minister for Finance).

${ }^{187}$ Vehicle Income Tax (VIT) is a tax designed for commercial transport operators. Due dates for payment of VIT are 15th January, 15th April, 15th July and 15th October. See https://gra.gov.gh/vehicle-income-tax / [Accessed on $10^{\text {th }}$ December 2020]. 
revenues? A parallel example is the role chiefs perform today in the HIV / AIDS campaign and similar campaigns.

Nearly half of the individual respondents do not think chiefs and traditional leaders should be involved at some level in the tax system of Ghana. The other half thinks they should. The balance in the responses betrays a certain conflation of the issues by the respondents. Some respondents equated the involvement of the chieftaincy institution in the tax system to tax collection. When they were prodded, however, they recognized other roles that chiefs could play in the tax system.

We have already suggested that chiefs should do some amount of symbolic tax collection in order to improve the image of the taxman at the local level, encourage voluntary tax compliance and have a sense of the issues in tax mobilization, the better to resolve tax disputes and protect the tax rights of their citizenry.

Chiefs could limit their intervention in tax mobilization to encouraging their citizenry to pay taxes, although in our research we have come across at least one instance, in the Upper West Region, where a chief successfully collected taxes for the District Assembly. Chiefs could also disseminate tax information and engage in some forms of tax education of their citizenry. This type of education could be through the medium of regular community gatherings.

Chiefs could be involved in tax dispute resolution at the level of the chiefs' courts, which they hold with their elders. Alternatively, the jurisdiction of the Traditional Councils could be expanded to include tax dispute resolution. As noted earlier, this latter option might get tax dispute resolution stymied in all the problems of delays and technicalities of the regular courts. The former suggestion is preferable, save that the phenomenon of the "absentee chief", also noted earlier, may make the operation of the chiefs' courts less effective and efficient than it could have been.

There is a strong case for the expansion of the jurisdiction of the chiefs' courts. Some of the compelling reasons are use of the local language in which parties and adjudicators are at ease and well versed, the absence of technical jargon, simple understandable procedures and nearness in location to the parties. To effectively resolve simple tax cases, chiefs may need to be introduced to new techniques in adjudication and alternative dispute resolution and the substance of tax laws.

Chiefs should also work on making the processes of tax collection, tax administration and the utilization of tax resources at the District Assembly level more transparent, accountable and user-friendly to their peoples. Most

1881992 Constitution of Ghana, Article 267(6)(a)

${ }^{189}$ Head Of Family (Accountability) Law 1985, (PNDCL 114).

${ }^{190}$ Gyamfi and Another v. Owusu and Others [1981] GLR 612 - 633

191 Oseadeeyo Addo Dankwa III, Paramount Chief of Akuapim

Traditional Area (2004) The Institution of Chieftaincy in Ghana - The
District Assemblies work closely with the chiefs in their jurisdiction and many chiefs are members of the District Assemblies. This will facilitate - for the chiefs - the process of ensuring clean governance in local level taxation. All this can be done in the broader context of the protection of the rights of taxpayers by traditional authorities.

At least one chief expressed the often-undeclared fears of the taxpayer when she is reluctant to involve chiefs in tax administration. He cautioned that there should be some monitoring to prevent some chiefs from using up tax revenues for their personal needs. The awe and reverence for chiefs is not always completely positive. Chiefs have wide discretion in shifting revenues gotten from their citizens to what - in their opinion - is the best use of those resources. Some chiefs have described the portion of stool land revenue that goes to the stool ${ }^{188}$ as an "unaccountable imprest". It is difficult to hold chiefs accountable in Ghana in the regular courts. We have a "Head of Family Accountability Law" in Ghana ${ }^{189}$ but not a Chiefs' Accountability Law. Although the judges have created some openings for assailing the solid customary rule that it was not possible to hold a chief accountable by judicial means for revenues collected by him $^{190}$, this is yet to be effectively tested.

Despite these concerns, "the future of Chieftaincy depends on its ability to adapt itself effectively to changing conditions without losing its basic attributes. ${ }^{\prime 191}$ Chiefs are aware of this and know that their involvement in developmental issues such as taxation has the potential to further this goal.

\section{CONCLUSION}

Taxation is important for national development. It is so important that we tend to concentrate on the critical matters of tax mobilization and compliance, mostly ignoring the soft aspects such as Tax Culture. This article demonstrates that Tax Culture is not only an amalgam of hard and soft aspects of taxation, but is indispensable to a successful system of tax administration. It is therefore critical to appropriately define a country's Tax Culture, isolate its constitutive elements, and understand each of the elements (including their history) and figure out how each element may be improved.

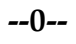

Future. Published with the support of Konrad Adenauer Foundation Accra, Ghana. p.vi. 


\section{How to cite this article:}

Atuguba, R. A. (2021). Tax Culture: Perspectives from an African State. American Journal of Trade and Policy, 8(1), 2558. https://doi.org/10.18034/ajtp.v8i1.510 